\title{
Paleo-environmental controls on cold seep carbonate authigenesis in the Sea of Marmara
}

\author{
Antoine Crémière ${ }^{\mathrm{a}, *}$, Germain Bayon ${ }^{\mathrm{b}}$, Emmanuel Ponzevera ${ }^{\mathrm{b}}$, Catherine Pierre ${ }^{\mathrm{a}}$ \\ a Université Pierre et Marine Curie, LOCEAN, UMR 7159, Paris, France \\ b IFREMER, Unité de Recherche Géosciences Marines, Plouzané, France \\ *: Corresponding author : Antoine Crémière, tel.: +33144278479 ; fax: +3314427 7159 ; \\ email address : antoine.cremiere@locean-ipsl.upmc.fr
}

\begin{abstract}
:
The factors controlling fluid emission dynamics at ocean margins are poorly understood. In particular, there are significant uncertainties on how fluid seepage at cold seeps may have responded to abrupt environmental changes in the geological past. This study reports on a detailed geochemical investigation of seafloor carbonate crusts sampled at cold seeps along the submerged part of the North Anatolian Fault system in the Sea of Marmara - an inland sea, which has experienced major paleo-environmental changes over the last deglaciation period. We also analyzed a series of authigenic carbonate concretions recovered from two sediment cores at the Western-High ridge, an active fluid venting area.
\end{abstract}

The ages of seafloor carbonate crusts derived from isochron $\mathrm{U}-\mathrm{Th}$ dating cover the last $7 \mathrm{kyr}$, suggesting that fluid activity along the fault system remained continuous over that time interval. In the sediment cores, carbonate concretions are concentrated at the lacustrine-to-marine transition, which corresponds to the period when Mediterranean waters flowed into the Marmara Basin about 12-14 kyr ago. U-Th isotopic data indicate that most of these concretions formed later during the Holocene, around 9-10 kyr ago, a period coinciding with an important anoxic event that led to the deposition of a sapropel layer in the Sea of Marmara.

Based upon these results, we suggest that the absence of carbonate concretions in the lacustrine sediment unit indicates that dissolved sulfate concentrations in the Marmara lake pore waters during glacial time were too low to promote significant anaerobic methane oxidation, thereby preventing sedimentary carbonate authigenesis. In contrast, the progressive inflow of Mediterranean waters into the glacial Marmara lake after 15 ka provided a source of dissolved sulfate that allowed anaerobic oxidation of methane to proceed within the anoxic sediment. Importantly, the synchronism between the main phase of authigenic carbonate precipitation at the studied sites (average $9.4 \pm 1.8 \mathrm{ka}, n=16$ ) and the regional anoxic sapropel event support the idea that the drop in bottom water dissolved oxygen content was probably a key factor to enhance microbial activity and associated carbonate precipitation at that time. Overall, these results provide straightforward evidence that fluid emission dynamics and hydrocarbon oxidation at cold seeps can be directly related to changing environmental conditions through time. 


\section{Highlights}

Authigenic carbonate dating reveals fluids flow over the last $13 \mathrm{kyr}$ in Marmara Sea Carbonate authigenesis (9-10 kyr) correspond to major paleo-environmental changes D During the LGM, AOM turnover in lake sediments was brought to be low - Sulfate input by Mediterranean waters incursion allowed AOM $>$ Carbonate precipitation correlates with sapropelic event

Keywords: U-Th dating ; authigenic carbonates ; Sea of Marmara ; cold seeps ; sapropel event ; carbon and oxygen isotopes

\section{Introduction}

Since their first discovery in the Gulf of Mexico (Paull et al., 1984), hydrocarbon-rich fluid discharges on the seafloor have been widely reported at ocean margins, typically hosting chemosynthetic communities and in association with authigenic carbonate deposits (for review see Campbell, 2006; Judd and Hovland, 2007; Sibuet and Olu, 1998). Substantial amounts of methane and other hydrocarbons transit in cold seeps zones representing a significant component in the global carbon cycle. In these environments, the mineralization of methane-derived authigenic carbonates represents an essential sink for carbon. Despite this significance, the global factors driving fluid seepage activity at ocean margins through time remain poorly understood. In particular, there is a gap on definitive knowledge on how cold seeps may respond to large-scale environmental changes, such as those that have been induced in the recent geological past by the alternance between glacial and interglacial periods. These considerations could have major implication on our understanding of the paleobiogeochemical fluxes at ocean margins, with possible significance in the context of the foregoing climate change.

At cold seeps, authigenic carbonate precipitation is induced by anaerobic oxidation of methane (AOM) coupled to sulfate reduction at the sulfate methane transitions zone (SMTZ) 
in marine sediments (Boetius et al., 2000; Hinrichs et al., 1999; Knittel et al., 2005; Orphan et al., 2001; Reeburgh, 1976; Valentine, 2002; Valentine and Reeburgh, 2000). AOM is mediated by a microbial consortium of methane-oxidizing archaea and sulfate-reducing bacteria which oxidize methane with sulfate, following the chemical reaction:

$$
\mathrm{CH}_{4}+\mathrm{SO}_{4}^{2-} \rightarrow \mathrm{HCO}_{3}^{-}+\mathrm{HS}^{-}+\mathrm{H}_{2} \mathrm{O}
$$

The production of bicarbonate and hydrogen sulfide increases carbonate alkalinity at the SMTZ which induces precipitation of carbonate minerals and pyrite (e.g. Peckmann et al., 2001; Ritger et al., 1987; Sassen et al., 2004)

Because authigenic carbonates remain stable in the geological record, they are reliable archives of paleo-cold seep activity and related environmental parameters. For instance, the carbon isotopic composition $\left(\delta^{13} \mathrm{C}\right)$ of carbonates represents a complex mixture of different carbon pools that possibly feeds carbonate precipitation and indirectly identifies the source of fluids from which they have precipitated. In addition, the oxygen isotopic composition $\left(\delta^{18} \mathrm{O}\right)$ can provide information on both the temperature and the isotopic composition of fluids in equilibrium during carbonate formation (e.g. Aloisi et al., 2000; Feng et al., 2010a; Gontharet et al., 2007; Greinert et al., 2001; Han et al., 2004; Magalhães et al., 2012; Peckmann and Thiel, 2004; Ritger et al., 1987; Stakes et al., 1999; Vanneste et al., 2012). In comparison, the temporal evolution of fluid dynamic at cold seeps is generally poorly constrained, mainly because authigenic carbonate minerals incorporate a substantial amount of dead carbon that makes conventional radiocarbon dating unsuitable. Nowadays, uranium-thorium dating methods represent the most suitable technique to constrain the temporal activity of cold seeps (Aharon et al., 1997; Bayon et al., 2009; Feng et al., 2010b; Kutterolf et al., 2008; Lalou et al., 1992; Liebetrau et al., 2010; Teichert et al., 2003; Watanabe et al., 2008).

This study reports absolute U-Th ages for a series of seep carbonates samples, together with more conventional stable carbon and oxygen isotopic data. The authigenic carbonates 
studied here were collected on the seafloor at several locations along the fault system and in

103 sedimentary records from the Western-High ridge in the Sea of Marmara (northeastern

104 Anatolia area; Fig. 1). The Sea of Maramara has experienced large environmental changes

105 since the last glacial maximum (i.e. the last $20 \mathrm{kyr}$ ), which make it a well suited natural

106 laboratory for investigating the response of fluid seepage to various environmental parameters,

107 such as dissolved sulfate and oxygen concentrations in bottom waters.

\section{Background}

\subsection{Geological setting}

Located at the intersection of four tectonic plates, the Anatolian region is one of the

111 most seismically active zone in the world. In its northwestern part, the inland Sea of Marmara

112 pull-appart (Armijo et al., 1999) is crossed east-to-west by the western extension of the North

113 Anatolian Fault (Fig. 1). This strike-slip fault is the expression of the transform plate

114 boundary between the Eurasian plate and the Anatolian block, which accommodates motion 115 of 20-25 mm/yr (Armijo et al., 1999; Armijo et al., 2002; McClusky et al., 2000; Reilinger et

116 al., 1997). Along its submerged segment, the fault divides in a complex system of main and

117 secondary branches (Bécel et al., 2010; Carton et al., 2007; Hergert and Heidbach, 2010).

118 Extensive seafloor gas flares are associated with the fault network, as inferred from the

119 occurrence of acoustic anomalies in the water column (Géli et al., 2008).

\subsection{Late Quaternary oceanographic evolution}

A major environmental change occurred in the Sea of Marmara during the last glacial maximum (LGM) when the global sea level was approximately $120 \mathrm{~m}$ lower than today

123 (Yokoyama et al., 2000) which resulted in the isolation of the Sea of Marmara from the

124 Mediterranean Sea via the Dardanelles sill. At that time, the Sea of Marmara became a large

125 brackish water lake (Aksu et al., 2002; Çağatay et al., 2000; McHugh et al., 2008; Stanley and 
Blanpied, 1980). From 14.7 ka before present (BP), and for about $2 \mathrm{kyr}$, the marine

127 transgression accompanying the onset of the deglaciation led to the progressive reconnection

128 of the Sea of Marmara to the Mediterranean Sea (Vidal et al., 2010). During this transition

129 episode, a thin layer of authigenic calcite was deposited from 13 to 11.5 cal kyr BP,

130 interpreted as a result of the mixing between oxic and salty Mediterranean waters and the

131 brackish (mainly anoxic) lake waters (Reichel and Halbach, 2007). The Holocene period

132 recorded in Marmara Sea sediments is characterized by the onset of two anoxic events,

133 inferred from the presence of sapropel deposits. The first sapropel event occurred between

13411.5 to $7 \mathrm{cal}$ kyr BP, associated with a major reorganization of phytoplankton populations.

135 The second one, less prominent, took place between 4.7 and 3.5 cal kyr BP (Aksu et al., 2002;

136 Çağatay et al., 1999; Çağatay et al., 2000; Sperling et al., 2003; Tolun et al., 2002; Vidal et al., 137 2010).

138 At present, the Marmara Sea is a two-layer stratified system with a strong permanent

139 pycnocline (Besiktepe et al., 1994). Inflow of surface waters from the Black Sea results in the

140 presence of brackish organic-rich upper water layer (20-40 m thick). Below, the sub-halocline

141 waters are characterised by low dissolved oxygen contents, but ventilation of this water mass

142 by denser saline Mediterranean waters prevents anoxia (Ergin et al., 1993).

\subsection{Previous studies}

In the Sea of Marmara, the distribution of seep sites is widespread, but mainly concentrated along the fault system. Methane sources in the basin depot centers (Tekirdağ,

146 Central and Çinarcik; Fig. 1) are mainly microbial (e.g. $\delta^{13} \mathrm{C}-\mathrm{CH}_{4}=-64 \%$ VPDB in the

147 Çinarcik basin Bourry et al., 2009), deriving from the microbial degradation of sub-surface

148 organic-rich sediments. Seafloor observations reveal that the fluids emitted from carbonate

149 chimneys at the eastern edge of the Çinarcik and Central basins were derived from brackish

150 water (Zitter et al., 2008). The emission of brackish water at these sites was also inferred from 
sediment pore water freshening, which disclosed that the fluids were derived from late glacial lacustrine sediment sequences (Tryon et al., 2010; Zitter et al., 2008).

These three deep basins are separated by two transpressional push-up structures, the Western and Central highs that stand at about $600 \mathrm{~m}$ water depth (Fig. 1). At the WesternHigh ridge, the active fault plumbing system provides migration pathways for deep-seated fluids including thermogenic gas, oil and brines (Bourry et al., 2009; Tryon et al., 2010). The main fluid seeps are localized north of the main fault along the anticlinal ridge, which correspond to two $10 \mathrm{~m}$ high mound-shaped structures interpreted as mud volcanoes (Géli et al., 2008). These structures are associated with carbonate and barite deposits. The occurrence of thermogenic gas hydrates has also been reported in sediments from the Western-High ridge (Bourry et al., 2009; Tryon et al., 2010).

A few molecular investigations of seafloor carbonates and unconsolidated surficial sediments from active seepage areas in the Marmara Sea confirmed that AOM associated with sulphate reduction was a major biogeochemical process at these sites (Chevalier et al., 2011; Chevalier et al., 2013). These studies pointed out that the AOM microbial assemblages were dominated by a consortium of sulfate reducing bacteria and ANME-2 archaea, suggesting that methane consumption was sustained by high fluid flow (Blumenberg et al., 2004; Stadnitskaia et al., 2008).

\section{Material and Methods}

\subsection{Authigenic carbonates and sediment cores}

Seafloor authigenic carbonate samples were collected with the manned submersible Nautile during the Marnaut expedition (R/V Atalante; May-June 2007). Dives were conducted at 6 different sites along the fault system (Fig. 1). 
175 At the Western-High ridge, two sediment cores (MNT-KS14 and MNT-KS27, 660 m water

176 depth) were recovered from each of the two mound structures mentioned above, using a $10 \mathrm{~m}$

177 long Kullenberg piston corer (see location in Fig. 1). Details on the lithological description of

178 the cores can be found in Crémière et al. (2012). Identification of key sedimentary units was

179 done by combining nano- and microfossil observations and radiocarbon dating, which

180 provided robust age constraints for the studied sedimentary records.

181

182

\subsection{Microscopic observations}

183

Scanning electron microscopy (SEM) coupled with an energy dispersive X-ray

184 spectrometer (EDS) was carried out on fragments of selected samples, allowing observation

185 of microfacies and qualitative elemental analysis at the mineral scale.

186

\subsection{Carbonate content and stable isotopes analyses}

The determination of the bulk sediment carbonate content (wt \%) was performed in a

189 manual carbonate calcimeter. The stable carbon and oxygen isotope compositions were

190 measured on both micromilled carbonate cements and bulk sediment samples. Powdered

191 samples were digested with anhydrous orthphosphoric acid and the carbon dioxide produced

192 by this reaction was injected into a dual-inlet isotopic ratio mass spectrometer (details of the

193 method can be found in the supplementary materials). Isotopic compositions are reported in

194 conventional delta $(\delta)$ units relative to the Vienna PeeDee Belemnite reference (VPDB)

195 (Craig, 1957). Analytical precision $2 \sigma$ is $0.01 \%$ and reproducibility is $\pm 0.07 \%$ for $\delta^{13} \mathrm{C}$ and $196 \pm 0.12 \%$ for $\delta^{18} \mathrm{O}$ values. 


\subsection{U-Th measurements and age calculation}

198

199

200

201

202

203

204

205

206

207

208

209

210

211

212

213

214

215

216

217

Samples for U-Th dating were selected according to their mineralogy (aragonite) and based on microscopic observations. Aragonite is known indeed to incorporate less detrital material (i.e. less ${ }^{232} \mathrm{Th}$ ) than other rhombohedral high-Mg carbonate phases, and to display higher U contents (Lachniet et al., 2012). Polished sections for selected carbonate samples were carefully inspected to avoid areas containing detrital minerals, Fe-Mn oxides, organic matter or shell debris. Despite careful sampling, U-Th dating of micromilled seep carbonate samples still requires correction from the incorporation of inherited ${ }^{232} \mathrm{Th}$ into the carbonate matrix. Therefore, three bulk sediment samples (about $100 \mathrm{mg}$ each) from the studied cores were also analysed in order to determine the composition of the end-member used for correcting measured U-Th carbonate data from 'detrital' contamination.

The clean lab procedure for $\mathrm{U}$ and $\mathrm{Th}$ separation is detailed in supplementary materials. $\mathrm{U}$ and Th concentrations and isotopic ratios were determined with a Neptune MCICP-MS. Internal precision obtained on measured ${ }^{234} \mathrm{U} /{ }^{238} \mathrm{U}$ and ${ }^{229} \mathrm{Th} /{ }^{230} \mathrm{Th}$ ratios were generally better than $5 \%$ and $75 \%$, respectively.

U-Th carbonate ages calculations were performed in 2D and 3D; corrected from detrital contamination by the isochron method, using the ISOPLOT program (v. 3.71, Ludwig, 2009). Because the experimental end-member exhibited relatively high $\left({ }^{238} \mathrm{U} /{ }^{232} \mathrm{Th}\right)$ activity ratio $(2.82 \pm 0.08)$, possibly indicating the presence of calcareous coccoliths in the sediment (Fig. 4), isochron ages were also determined using a more conservative theoretical endmember at the secular equilibrium (activity ratios $=1.0 \pm 0.5$ ). Calculated ages using this theoretical end-member, though associated with larger uncertainties, were generally very similar to those determined with the experimental end-member (see supplementary materials), thereby providing reassuring evidence for the validity of the ages calculated with this first 
approach. Therefore, we decided to use the isochron ages provided by our experimental endmember.

\section{Results}

\subsection{Mineralogy and stable isotope geochemistry}

The seafloor carbonate deposits correspond to crusts or fractured slabs, sometimes piled up (Fig. 2). The great majority of the crusts used in this study $(\mathrm{n}=10)$ are composed predominantly of aragonite, occurring as acicular, isopachous and botryoidal crystals coated with dark-brown Fe-Mn oxyhydroxide phases (Fig. 2 and 3). Framboidal aggregates of pyrite and prismatic crystals of authigenic barite were observed in the carbonate matrix.

232 glacial-lacustrine sediments characterized by low carbonate contents $(<6 \% \mathrm{wt})$ contrasting

233 with numerous $\mathrm{cm}$-size carbonate concretions occurring near or within the transitional sedimentary unit (estimated between $\sim 14.5$ to $\sim 12$ cal kyr BP). However, the concretions mineralogy differs from each core; in core MNT-KS14 they are mainly composed of aragonite while those found in core MNT-KS27 correspond primarily to high Mg-calcite

237 (Crémière et al., 2012). At these two sites, the present-day SMTZ is encountered at around 50

238 cm below the seafloor (Tryon et al., 2010), well above the depths at which carbonate concretions occur in these sediments.

The stable isotopic compositions of micro-drilled carbonate samples vary between 45.2 to $+1.5 \%$ o VPDB for $\delta^{13} \mathrm{C}$ and +0.6 to $+3.6 \%$ VPDB for $\delta^{18} \mathrm{O}$ (Fig. 5). These values

242 range over those previously published for bulk carbonate samples from the same area

243 (Crémière et al., 2012). Samples from the basins exhibit the lowest $\delta^{13} \mathrm{C}$ values, whereas at 244 the Western-High ridge, carbonate crusts and concretions (from core MNT-KS 14) present 
moderately ${ }^{13} \mathrm{C}$-depleted ( - $15 \%$ VPDB) to slightly enriched (+1.5\% VPDB) $\delta^{13} \mathrm{C}$ values.

246 Most of the oxygen isotopic compositions are near to the equilibrium with ambient present 247 day bottom water $\left(\delta^{18} \mathrm{O}=+2.8 \%\right.$ o VPDB, (Crémière et al., 2012). However, some few 248 carbonate crusts display markedly lower values (+0.6\%o VPDB, at the Tekirdağ Basin) 249 whereas buried concretions present higher values (up to +3.6\% VPDB at the Western-High 250 ridge).

\subsection{U-Th data and carbonate ages}

Carbonate ${ }^{238} \mathrm{U}$ and ${ }^{232} \mathrm{Th}$ concentrations range from $\sim 0.5$ to $12.5 \mathrm{ppm}$ and 5 to 2800 $254 \mathrm{ppb}$, respectively (see supplementary materials). Comparatively, average values for our sediment end-member are similar for U (3.7 ppm), but much higher for Th ( 4000 ppb). The corrected initial values of $\delta^{234} \mathrm{U}$ (3D-isochrons calculated with the experimental end-member) for carbonate samples range from 150 to $213 \%$ (average $166 \pm 13 \%$ ), higher than both Mediterranean waters (149.4 $\pm 0.6 \%$, Delanghe et al., 2002) and the mean modern seawater value (146.6 $\pm 2.5 \%$ o Robinson, 2004).

The seafloor carbonate crusts display U-Th ages that vary from about 0.4 to $6.6 \mathrm{ka}$,

261 although most samples appear to have precipitated during the last $5 \mathrm{kyr}$ (average $2.9 \pm 2.1 \mathrm{ka}$, $262 \mathrm{n}=13$ ) (Fig. 6). U-Th ages determined for carbonate concretions from Western-High ridge 263 sediments cluster between $\sim 9-10 \mathrm{kyr}$ (average $9.4 \pm 1.8 \mathrm{ka}, \mathrm{n}=16$ ), within a global range 264 between 6.2 to $13.6 \mathrm{kyr}$. 


\section{Discussion}

267

268

269

270

271

272

273

274

275

276

277

278

279

280

281

282

283

284

285

286

287

\subsection{Stable isotope and mineralogical constraints on the source of fluids}

The large variations of ${ }^{13} \mathrm{C}$-depleted values (-45.2 to $-2.3 \%$ VPDB) measured in our carbonate samples testify of differences in fluid sources (microbial methane versus thermogenic hydrocarbons) and in biogeochemical processes (AOM, methanogenesis and organoclastic sulfate reduction) that can supply DIC in pore waters with distinct stable isotopic signatures. The ${ }^{13} \mathrm{C}$-depleted values of seafloor carbonate crusts indicate that they mainly derived from the anoxic microbial oxidation of methane-rich fluids. For instance, the characteristic carbon isotopic composition of carbonate samples from the Western-High ridge most likely reflects the presence of advecting ${ }^{13} \mathrm{C}$-rich alkaline deep fluids possibly caused by anaerobic biodegradation of hydrocarbons supporting secondary methanogenesis (Bourry et al., 2009; Pallasser, 2000; Ruffine et al., 2012). Furthermore, the presence oil-soaked carbonates at this site presumably indicate that the oxidation of hydrocarbons heavier than methane is a source of carbon moderately depleted in ${ }^{13} \mathrm{C}$ (Crémière et al., 2012; Formolo et al., 2004; Mansour and Sassen, 2011).

The oxygen isotopic composition of authigenic carbonates generally displays values close to the isotopic equilibrium calculated for the present-day bottom seawater $\left(\mathrm{T}=14.5^{\circ} \mathrm{C}\right.$ and $\delta^{18} \mathrm{O}=+1.4 \%$ SMOW) suggesting that most of the studied carbonate samples have precipitated in the near seafloor environment. An exception are the low carbonate $\delta^{18} \mathrm{O}$ values encountered in the eastern part of the Tekirdağ Basin, which most probably indicate a contribution from brackish waters incoming from glacial sediments (Zitter et al., 2008) and expelled thought recent fractured fault zone (authigenic carbonates dated between 0.6 to 2.5 kyr). On the other hand, the oxygen isotopic disequilibrium observed at the Western-High ridge may reflect the imprint of fluids carrying distinctive diagenetic $\delta^{18} \mathrm{O}$ signatures, affected 
by deep diagenetic reactions such as clay dehydration and/or by the shallower influence of gas

291 hydrate formation/dissociation (Hesse and Harrison, 1981; Sheppard and Gilg, 1996; Tryon et 292 al., 2010).

293 One striking feature of our results is the marked difference in mineralogy between 294 carbonate concretions from core MNT-KS14 (aragonite) and MNT-KS27 (high Mg-calcite, 295 Crémière et al., 2012). The very distinctive $\delta^{13} \mathrm{C}$ signatures of the authigenic carbonate 296 samples from these two sites point toward different fluid sources (Fig. 7). Found at the 297 lacustrine-marine transition, aragonite-rich phases (sometimes mixed with high Mg-calcite) 298 with depleted $\delta^{13} \mathrm{C}$ values around -18\%o VPDB, are most probably derived from the microbial 299 oxidation of methane and also possibly from heavier hydrocarbons mixed with minor amounts 300 of $\delta^{13} \mathrm{C}$-rich DIC from deep seated fluids. In contrast, high-Mg calcite rich phases are 301 enriched in ${ }^{13} \mathrm{C}$, which possibly reflects an important contribution from deep-sourced fluids. The carbonate mineralogy depends on multiple factors such as temperature, saturation 303 state, dissolved sulfate concentration, $\mathrm{Ca}^{2+} / \mathrm{Mg}^{2+}$ pore water ratio, and microbial metabolism 304 are likely to influence their formation (Burton, 1993; Burton and Walter, 1987; Morse et al., 305 1997; Savard et al., 1996). Aragonite precipitation is favored over calcite in cold seeps 306 environments at high rates of AOM sustained by vigorous methane fluxes, which results in 307 oversaturation with respect to $\mathrm{HCO}_{3}{ }^{-}$at relatively high pore water $\mathrm{SO}_{4}{ }^{2-}$ concentrations near 308 the seafloor (Aloisi et al., 2002; Aloisi et al., 2000; Greinert et al., 2001; Luff and Wallmann, 309 2003; Nöthen and Kasten, 2011; Peckmann et al., 2001; Savard et al., 1996). Based upon 310 these considerations, we propose that concretions containing aragonite and occurring close to 311 the lacustrine-marine transition have precipitated near the seafloor in relation with intense 312 fluid seepage activity, whereas ${ }^{13} \mathrm{C}$-enriched high $\mathrm{Mg}$-calcite concretions intercalated in the 313 upper marine deposits of core MNT-KS27 were formed most likely as a result of a diffusive $314 \mathrm{CH}_{4}$ flux, thereby recording the composition of $\delta^{13} \mathrm{C}$ rich-DIC deep seated fluids. The fact 
that thermogenic gas hydrates were recovered at the bottom of core MNT-KS27 (Bourry et al.,

316 2009) whereas there is no evidence of their occurrences in core MNT-KS14 (Tryon et al.,

317 2010), probably also indicate that high Mg-calcite carbonates precipitation at this site could

318 be related to diffusive upward flux of hydrocarbons in response to gas hydrates dissociation

319 and dissolution, as proposed elsewhere for other hydrate-bearing settings (Bahr et al., 2010;

320 Bohrmann et al., 1998; Greinert et al., 2001; Nöthen and Kasten, 2011). Because these gas

321 hydrates also contain a significant amount of $4 \% \mathrm{CO}_{2}$ with a $\delta^{13} \mathrm{C}-\mathrm{CO}_{2}$ at $+29 \%$ VPDB

322 (Bourry et al., 2009), their dissociation might lead to higher $\mathrm{pCO}_{2}$ in pore water which will

323 both reduce carbonate precipitation rate and also increasing $\delta^{13} \mathrm{C}$-DIC content in pore fluids.

\subsection{Controls on carbonate authigenesis}

5.2.1 Seafloor carbonate crusts related to fluid circulation along the fault system

Temporal variations of fluid discharge at cold seeps have been recorded in authigenic

carbonates covering 5 to 50 kyr periods of highly activity (Bayon et al., 2009; Kutterolf et al., 2008; Liebetrau et al., 2010; Watanabe et al., 2008). Several studies have shown the potential seismically activity control on fluid circulation along major fault systems (e.g. Field and

331 Jennings, 1987; Mau et al., 2007; Obzhirov et al., 2004), including the Marmara Sea (Alpar, 1999; Halbach et al., 2004; Kuscu et al., 2005). This implies that past emissions of hydrocarbon-rich fluids (and associated carbonate precipitation) along the Marmara fault system were also controlled, at least partly, by the occurrence of seismo-tectonically events.

335 In this context, evidence that our calculated U-Th ages for the studied seafloor carbonate

336 crusts cover the entire last 7 kyr period most probably indicates continuous fluid seepage and 337 seismic activities along the fault system during that time interval. 
339 (1-3 m/kyr, Armijo et al., 2005), the presence of thousand years-old carbonate crusts

340 outcropping at the seafloor may seem unexpected. However, pelagic sediments can be easily

341 resuspended through the action of bottom currents by winnowing or, perhaps more likely in

342 the case of this study, during vigorous fluid emission observed throughout in-situ dives at the

343 seafloor. This would be in agreement with the presence of a thin layer of oxy-hydroxides

344 coating on most of the studied seafloor carbonate crusts, which may reflect the oxidation of

345 dissolved reduced $\mathrm{Fe}$ and Mn during fluid venting (Bayon et al., 2011; Crémière et al., 2012).

346 Although little is known about carbonate precipitation rates at cold seeps, Bayon et al.

347 (2009) reported the first experimental stratigraphy for an authigenic carbonate crust in the

348 eastern Mediterranean sea, showing evidence for growth rates ranging from $\sim 0.4$ to $5 \mathrm{~cm}$ per

349 kyr. These experimental data were in agreement with modeling studies, suggesting that $\mathrm{cm}-$

350 thick authigenic carbonate crusts could form within a few hundred years (Luff et al., 2004).

351 These results suggest that the ages calculated for our discrete milligram-size samples are

352 globally representative (at least within about a thousand years) of the mean precipitation age

353 of the studied bulk carbonate samples. This provides further support to our hypothesis of a

354 near continuous fluid seepage activity along the Marmara fault system during the last $7 \mathrm{kyr}$.

\subsubsection{Carbonate concretions and the record of paleo-environmental changes}

At the core sites, carbonate concretions occur within a well-defined horizon below the the present-day SMTZ (Fig. 8). Interestingly, the U-Th carbonate ages of these concretions (average $9.4 \pm 1.8 \mathrm{ka}, \mathrm{n}=16$ ) differ from the corresponding stratigraphic ages for core MNT-

360 KS14 (about 11-14 ka). Based on the sedimentation rate, the sediment depth formation of

361 these concretions can be estimated between about a few down to $40 \mathrm{~cm}$ below the seafloor, corresponding most probably at the depth of a paleo-SMTZ. The observed frequency of U-Th 
ages lends support to the hypothesis that they correspond to a major phase of carbonate precipitation centered about 9-10 kyr ago. To some extent, the synchronicity of this carbonate precipitation event is also expressed by the linear trend defined by all carbonate concretions on the isochron plot in Fig. 6.

There after, several possible causes that could have accounted for this carbonate precipitation event in the early Holocene period will be discussed. First of all, the influence of the mixing between marine Mediterranean waters and the glacial Marmara lacustrine lake, which led to the precipitation of a disseminated authigenic calcite layer about 12 cal kyr BP ago (Reichel and Halbach, 2007), seem to be discarded because it almost completely occurred before the main episode of authigenic carbonate precipitation (Fig. 9).

Fluid flow intensity at margins has been sensitive to past sea level changes over glacial and inter-glacial cycles. For instance, low sea level stand periods has increased fluids seepage activity by reducing hydraulic pressure exerted by the water column and by reducing gas hydrate stability flied in marine sediments (Kennett et al., 2000; Teichert et al., 2003; Tryon et al., 2002; Watanabe et al., 2008; Wood et al., 2002). Negative $\delta^{13} \mathrm{C}$ excursions in Late Quaternary sedimentary records have been documented in both benthic and planktonic foraminifers and interpreted as the consequence of methane hydrate dissociation events triggered by bottom water warming or hydrostatic pressure drop (Garidel-Thoron et al., 2004; Hill et al., 2004; Kennett et al., 2000; Millo et al., 2005). In the Marmara Basin, Ménot and Bard (2010) have documented ${ }^{13} \mathrm{C}$-depleted lipid biomarkers linked to the methanotrophic activity, in a sediment core (MD012430; $580 \mathrm{~m}$ water depth) located about $5 \mathrm{~km}$ southwest away from our studied sites. Sediment layers dated from 12.7 to 9.5 cal kyr BP exhibited high concentrations of specific lipid biomarkers that are indicative of aerobic methane oxidation in the water column. Based on these results, the authors postulated that methane hydrates stored in Marmara Basin sediments ( 1300 m water depth) had dissociated in response to bottom- 
water warming at the onset of the last deglaciation. Although gas hydrate dissociation in the deeper Marmara Basin represents indeed a conceivable explanation for the release of substantial amounts of methane into the water column at that time, it is unlikely to have accounted for the inferred increase of the methane flux at our studied site given that is located at much shallower depth on the Western-High ridge ( 660 m) which is out of gas hydrates (type I) stability zone (Bourry et al., 2009; Menot and Bard, 2010). Considering the global sea level curves from Lambeck et al., (2002) and the depth of 395 the Dardanelles sill level $(\sim 80 \mathrm{~m})$, the period of carbonate formation at our site occurred 396 towards the end of sea level rise during the last deglaciation (Fig. 10) whereas most of the 397 carbonates were formed during glacial time (e.g. Teichert et al., 2003; Watanabe et al., 2008). 398 Probably, this suggests that our inferred enhanced flux of hydrocarbons at that time was not 399 directly caused by sea level fluctuation. Interestingly, a major anoxic event related to high 400 primary productivity and biogeochemical cycles reorganization is contemporaneous with our 401 carbonate precipitation period (Fig. 9 and 10). This paleo-redox change has been described 402 previously in many sediment cores all over the Marmara Sea (Abrajano et al., 2002; Aksu et 403 al., 2002; Aksu et al., 1999; Çağatay et al., 2000; Kirci-Elmas et al., 2008; Sperling et al., 404 2003; Vidal et al., 2010). The range of U-Th carbonates ages calculated for core MNT-KS14 405 concretions coincides well with the duration of the sapropel event. Most likely, decreasing 406 oxygen contents in the Marmara Sea at that time preserved organic carbon export toward the 407 seafloor, thereby leading to increase in-situ rates of methanogenesis. Consequently, this 408 paleo-environmental change had possibly sustained microbial oxidation processes and 409 authigenic carbonate precipitation in sub-surface sediments, both by increasing methane flux 410 and by creating favorable conditions for methanotrophic archaea (sensitive to the oxygen 411 front). This assumption would be consistent with the ${ }^{13} \mathrm{C}$-depleted values of the carbonate 
412 concretions found close to the lacustrine-marine transition in contrast with the concretions

413 found in the upper marine deposits (see discussion in 5.1 and Fig. 8).

414 Another important parameter that is required to promote AOM and associated

415 carbonate precipitation is the presence of dissolved sulfate in pore waters. Rates of anaerobic

416 methane oxidation coupled with sulfate or other terminal electron acceptors (e.g. nitrate, iron,

417 manganese...) are known to be particularly low in modern lake sediments (e.g. Deutzmann

418 and Schink, 2011; Eller et al., 2005; Knittel and Boetius, 2009). Similarly, previous studies

419 have shown that decreasing sulfate availability in pore waters at cold seeps can lead to much

420 reduced rates of methane turnover and consequently carbonate precipitation (Bayon et al.,

421 2009; de Beer et al., 2006). The absence of carbonate concretions in most of the glacial

422 lacustrine sedimentary unit (Fig. 8) suggests most likely that dissolved sulfate contents in the

423 glacial brackish Marmara lake were too low to promote substantial consumption of methane

424 in sediments by AOM.

425 Thus, during the late glacial period, it seems reasonable to argue that methane-rich

426 fluids were directly escaping the seafloor into the sulfate-free water column, being possibly

427 oxidized aerobically within the lake and/or migrating up to surface waters and perhaps up to

428 the atmosphere. In marked contrast, the invasion of marine Mediterranean waters into the

429 Marmara Sea from about 15-12 ka created suitable conditions for sustaining anaerobic

430 methane oxidation and associated authigenic carbonate precipitation in sub-surface sediments

431 over the last $13 \mathrm{ka}$.

432 Based on our results, we propose that paleo-carbon cycle within oceanic margins and

433 the carbon sink generated by authigenic carbonate precipitation that took place over

434 geological past was controlled by AOM activity which (1) was possibly limited by the sulfate

435 availability in marine sediments while (2) past anoxic events have increased carbon dynamic 
in marine sediments (Schrag et al., 2013) by providing carbon-rich substrates and thus

437 sustaining microbial activity.

\section{Conclusion}

440 Along the submerged North Anatolia fault in the Marmara Sea, seafloor authigenic

441 carbonate crusts and buried concretions exhibit U-Th ages covering the past $13 \mathrm{kyr}$,

442 suggesting near continuous fluid seepage activity associated with the fault system during that

443 time period. Aragonite-rich concretions collected within a sediment core at the Western-High

444 ridge document enhanced carbonate precipitation event between 9 to $10 \mathrm{kyr}$. This is

445 interpreted as the result of the sulfate-rich Mediterranean water inflow about 13 ka ago and

446 the onset of a major anoxic sapropel event rather than a sea level control on methane emission.

447 Our findings provide important insights into paleo-environmental parameters that

448 influence carbon cycling at the sediment-water interface and microbially-mediated authigenic

449 carbonates precipitation in cold seep environments. Dissolved sulfate limitation and paleo-

450 redox changes in bottom waters are likely to represent primary factors allowing microbial

451 methane turnover in sub-surface sediments and possibly controlling fluid seepage activity

452 through geological time. In the neighbouring Black Sea, which is the largest modern anoxic

453 basin on Earth, intense microbial activity has been reported extended up to the water column,

454 leading to the edification of massive carbonate chimneys on the seafloor (Luth et al., 1999;

455 Peckmann et al., 2001). By analogy, anoxic events that occurred elsewhere during the

456 geological past had probably also a strong impact on the emission of methane fluxes and

457 microbial carbon cycling through time. Nevertheless, further investigations are now needed in

458 order to better understand and quantify how drastic environmental changes in the past, such as

459 sudden shift in dissolved oxygen or sulfate concentrations may have affected carbon cycling

460 and associated microbial oxidation processes in anoxic sediments. 


\section{Acknowledgements}

463

We acknowledge the Captain, crewmembers and scientific team on board during the Marnaut cruise of the R/V Atalante for their great contribution. We thank Vincent Rommeveaux for his technical support during polish section preparation and Omar Boudouma for his guidance during SEM-EDS investigations. The authors are grateful to comments provided by 3 anonymous reviewers.

\section{References}

Abrajano, T., Aksu, A.E., Hiscott, R.N., Mudie, P.J., 2002. Aspects of carbon isotope biogeochemistry of late Quaternary sediments from the Marmara Sea and Black Sea. Marine Geology 190, 151-164.

Aharon, P., Schwarcz, H.P., Roberts, H.H., 1997. Radiometric dating of submarine hydrocarbon seeps in the Gulf of Mexico. Geological Society of America Bulletin 109, 568579 .

Aksu, A.E., Hiscott, R.N., Kaminski, M.A., Mudie, P.J., Gillespie, H., Abrajano, T., Yasar, D., 2002. Last glacial-Holocene paleoceanography of the Black Sea and Marmara Sea: stable isotopic, foraminiferal and coccolith evidence. Marine Geology 190, 119-149.

Aksu, A.E., Hiscott, R.N., Yasar, D., 1999. Oscillating Quaternary water levels of the Marmara Sea and vigorous outflow into the Aegean Sea from the Marmara Sea-Black Sea drainage corridor. Marine Geology 153, 275-302.

Aloisi, G., Bouloubassi, I., Heijs, S.K., Pancost, R.D., Pierre, C., Sinninghe Damsté, J.S., Gottschal, J.C., Forney, L.J., Rouchy, J.-M., 2002. CH4-consuming microorganisms and the formation of carbonate crusts at cold seeps. Earth and Planetary Science Letters 203, 195-203.

Aloisi, G., Pierre, C., Rouchy, J.-M., Foucher, J.-P., Woodside, J., 2000. Methane-related authigenic carbonates of eastern Mediterranean Sea mud volcanoes and their possible relation to gas hydrate destabilisatio. Earth and Planetary Science Letters 184, 321-338.

Alpar, B., 1999. Underwater signatures of the Kocaeli Earthquake (August 17th 1999). Turkish J. Mar. Sci. 5, 111-130.

Armijo, R., Meyer, B., Hubert, A., Barka, A., 1999. Westward propagation of the North Anatolian fault into the northern Aegean: Timing and kinematics. Geology 27, 267-270. 
Armijo, R., Meyer, B., Navarro, S., King, G., Barka, A., 2002. Asymmetric slip partitioning in the Sea of Marmara pull-apart: a clue to propagation processes of the North Anatolian Fault? Terra Nova 14, 80-86.

Armijo, R., Pondard, N., Meyer, B., Ucarkus, G., de Lepinay, B.M., Malavieille, J., Dominguez, S., Gutscher, M.A., Schmidt, S., Beck, C., Çağatay, N., Cakir, Z., Imren, C., Eris, K., Natalin, B., Ozalaybey, S., Tolun, L., Lefevre, I., Seeber, L., Gasperini, L., Rangin, C., Emre, O., Sarikavak, K., 2005. Submarine fault scarps in the Sea of Marmara pull-apart (North Anatolian Fault): Implications for seismic hazard in Istanbul. Geochem. Geophys. Geosyst. 6.

Bahr, A., Pape, T., Abegg, F., Bohrmann, G., van Weering, T., Ivanov, M.K., 2010. Authigenic carbonates from the eastern Black Sea as an archive for shallow gas hydrate dynamics - Results from the combination of CT imaging with mineralogical and stable isotope analyses. Marine and Petroleum Geology 27, 1819-1829.

Bayon, G., Birot, D., Ruffine, L., Caprais, J.C., Ponzevera, E., Bollinger, C., Donval, J.P., Charlou, J.L., Voisset, M., Grimaud, S., 2011. Evidence for intense REE scavenging at cold seeps from the Niger Delta margin. Earth and Planetary Science Letters 312, 443-452.

Bayon, G., Henderson, G.M., Bohn, M., 2009. U-Th stratigraphy of a cold seep carbonate crust. Chemical Geology 260, 47-56.

Bécel, A., Laigle, M., de Voogd, B., Hirn, A., Taymaz, T., Yolsal-Cevikbilen, S., Shimamura, H., 2010. North Marmara Trough architecture of basin infill, basement and faults, from PSDM reflection and OBS refraction seismics. Tectonophysics 490, 1-14.

Besiktepe, Ș.T., Sur, H.I., Özsoy, E., Latif, M.A., Oğuz, T., Ünlüata, Ü., 1994. The circulation and hydrography of the Marmara Sea. Prog Oceanogr 34, 285-334.

Blumenberg, M., Seifert, R., Reitner, J., Pape, T., Michaelis, W., 2004. Membrane lipid patterns typify distinct anaerobic methanotrophic consortia. Proceedings of the National Academy of Sciences of the United States of America 101, 11111-11116.

Boetius, A., Ravenschlag, K., Schubert, C.J., Rickert, D., Widdel, F., Gieseke, A., Amann, R., Jorgensen, B.B., Witte, U., Pfannkuche, O., 2000. A marine microbial consortium apparently mediating anaerobic oxidation of methane. Nature 407, 623-626.

Bohrmann, G., Greinert, J., Suess, E., Torres, M., 1998. Authigenic carbonates from the Cascadia subduction zone and their relation to gas hydrate stability. Geology 26, 647-650.

Bourry, C., Chazallon, B., Charlou, J.L., Donval, J.P., Ruffine, L., Henry, P., Géli, L., Çağatay, M.N., Inan, S., Moreau, M., 2009. Free gas and gas hydrates from the Sea of Marmara, Turkey Chemical and structural characterization. Chemical Geology 264, 197-206.

Burton, E.A., 1993. Controls on marine carbonate cement mineralogy: review and reassessment. Chemical Geology 105, 163-179.

Burton, E.A., Walter, L.M., 1987. Relative precipitation rates of aragonite and Mg calcite from seawater - temperature or carbonate ion control. Geology 15, 111-114. 
Çağatay, M.N., Algan, O., Sakinc, M., Eastoe, C.J., Egesel, L., Balkis, N., Ongan, D., Caner, H., 1999. A mid-late Holocene sapropelic sediment unit from the southern Marmara sea shelf and its palaeoceanographic significance. Quat. Sci. Rev. 18, 531-540.

534 Çağatay, M.N., Görür, N., Algan, O., Eastoe, C., Tchapalyga, A., Ongan, D., Kuhn, T., Kuscu, connections with the Mediterranean and the Black Seas. Marine Geology 167, 191-206.

Campbell, K.A., 2006. Hydrocarbon seep and hydrothermal vent paleoenvironments and paleontology: Past developments and future research directions. Palaeogeography, Palaeoclimatology, Palaeoecology 232, 362-407.

Carton, H., Singh, S.C., Hirn, A., Bazin, S., de Voogd, B., Vigner, A., Ricolleau, A., Cetin, S., Ocakoglu, N., Karakoc, F., Sevilgen, V., 2007. Seismic imaging of the three-dimensional architecture of the Cinarcik Basin along the North Anatolian Fault. J. Geophys. Res.-Solid Earth 112.

Chevalier, N., Bouloubassi, I., Birgel, D., Crémière, A., Taphanel, M.-H., Pierre, C., 2011. Authigenic carbonates at cold seeps in the Marmara Sea (Turkey): A lipid biomarker and stable carbon and oxygen isotope investigation. Marine Geology 288, 112-121.

547 Chevalier, N., Bouloubassi, I., Birgel, D., Taphanel, M.H., López-García, P., 2013. Microbial methane turnover at Marmara Sea cold seeps: a combined 16S rRNA and lipid biomarker investigation. Geobiology 11, 55-71.

Craig, H., 1957. Isotopic standards for carbon and oxygen and correction factors for massspectrometric analysis of carbon dioxide. Geochimica Et Cosmochimica Acta 12, 133-149.

Crémière, A., Pierre, C., Blanc-Valleron, M.-M., Zitter, T., Çağatay, M.N., Henry, P., 2012. Methane-derived authigenic carbonates along the North Anatolian fault system in the Sea of Marmara (Turkey). Deep Sea Research Part I: Oceanographic Research Papers 66, 114-130. Boetius, A., 2006. In situ fluxes and zonation of microbial activity in surface sediments of the Håkon Mosby Mud Volcano. Limnol. Oceanogr 51, 1315-1331.

558 Delanghe, D., Bard, E., Hamelin, B., 2002. New TIMS constraints on the uranium-238 and 559 uranium-234 in seawaters from the main ocean basins and the Mediterranean Sea. Marine 560 Chemistry 80, 79-93.

561 Deutzmann, J.S., Schink, B., 2011. Anaerobic Oxidation of Methane in Sediments of Lake 562 Constance, an Oligotrophic Freshwater Lake. Applied and Environmental Microbiology 77, 563 4429-4436.

564 Eller, G., Känel, L., Krüger, M., 2005. Cooccurrence of Aerobic and Anaerobic Methane 565 Oxidation in the Water Column of Lake Plußsee. Applied and Environmental Microbiology $71,8925-8928$. 
Feng, D., Chen, D., Peckmann, J., Bohrmann, G., 2010a. Authigenic carbonates from methane seeps of the northern Congo fan: Microbial formation mechanism. Marine and Petroleum Geology 27, 748-756.

Feng, D., Roberts, H.H., Cheng, H., Peckmann, J., Bohrmann, G., Lawrence Edwards, R., Chen, D., 2010b. U/Th dating of cold-seep carbonates: An initial comparison. Deep Sea Research Part II: Topical Studies in Oceanography 57, 2055-2060.

Field, M.E., Jennings, A.E., 1987. Seafloor gas seeps triggered by a northern California earthquake. Marine Geology 77, 39-51.

Formolo, M.J., Lyons, T.W., Zhang, C., Kelley, C., Sassen, R., Horita, J., Cole, D.R., 2004. Quantifying carbon sources in the formation of authigenic carbonates at gas hydrate sites in the Gulf of Mexico. Chemical Geology 205, 253-264.

Garidel-Thoron, T.d., Beaufort, L., Bassinot, F., Henry, P., Kennett, J.P., 2004. Evidence for Large Methane Releases to the Atmosphere from Deep-Sea Gas-Hydrate Dissociation during the Last Glacial Episode. Proceedings of the National Academy of Sciences of the United States of America 101, 9187-9192.

Géli, L., Henry, P., Zitter, T., Dupre, S., Tryon, M., Çağatay, M.N., de Lepinay, B.M., Le Pichon, X., Sengor, A.M.C., Gorur, N., Natalin, B., Ucarkus, G., Oezeren, S., Volker, D., Gasperini, L., Burnard, P., Bourlange, S., Marnaut Scientific, P., 2008. Gas emissions and active tectonics within the submerged section of the North Anatolian Fault zone in the Sea of Marmara. Earth and Planetary Science Letters 274, 34-39.

Gontharet, S., Pierre, C., Blanc-Valleron, M.M., Rouchy, J.M., Fouquet, Y., Bayon, G., Foucher, J.P., Woodside, J., Mascle, J., 2007. Nature and origin of diagenetic carbonate crusts and concretions from mud volcanoes and pockmarks of the Nile deep-sea fan (eastern Mediterranean Sea). Deep Sea Research Part II: Topical Studies in Oceanography 54, 12921311.

Greinert, Jens, Bohrmann, Gerhard, Suess, Erwin, 2001. Gas hydrate-associated carbonates and methane-venting at Hydrate ridge : Classification, distribution, and origin of authigenic lithologies. American Geophysical Union, Washington, DC, ETATS-UNIS.

Halbach, P., Holzbecher, E., Reichel, T., Moche, R., 2004. Migration of the sulphate-methane reaction zone in marine sediments of the Sea of Marmara--can this mechanism be tectonically induced? Chemical Geology 205, 73-82.

Han, X., Suess, E., Sahling, H., Wallmann, K., 2004. Fluid venting activity on the Costa Rica margin: new results from authigenic carbonates. International Journal of Earth Sciences 93, 596-611.

Hergert, T., Heidbach, O., 2010. Slip-rate variability and distributed deformation in the Marmara Sea fault system. Nat. Geosci. 3, 132-135.

Hesse, R., Harrison, W.E., 1981. Gas hydrates (clathrates) causing pore-water freshening and oxygen isotope fractionation in deep-water sedimentary sections of terrigenous continental margins. Earth and Planetary Science Letters 55, 453-462. 
Hill, T.M., Kennett, J.P., Spero, H.J., 2004. High-resolution records of methane hydrate dissociation: ODP Site 893, Santa Barbara Basin. Earth and Planetary Science Letters 223,

611 127-140.

612 Hinrichs, K.-U., Hayes, J.M., Sylva, S.P., Brewer, P.G., DeLong, E.F., 1999. Methane-

613 consuming archaebacteria in marine sediments. Nature 398, 802-805.

614 Judd, A., Hovland, M., 2007. Seabed Fluid Flow. Cambridge University Press.

615 Kennett, J.P., Cannariato, K.G., Hendy, I.L., Behl, R.J., 2000. Carbon isotopic evidence for 616 methane hydrate instability during quaternary interstadials. Science 288, 128-133.

617 Kirci-Elmas, E., Algan, O., Ozkar-Ongen, I., Struck, U., Altenbach, A.V., Sagular, E.K., 618 Nazik, A., 2008. Palaeoenvironmental investigation of sapropelic sediments from the 619 Marmara Sea: A biostratigraphic approach to palaeoceanographic history during the last 620 glacial-Holocene. Turk. J. Earth Sci. 17, 129-168.

621 Knittel, K., Boetius, A., 2009. Anaerobic oxidation of methane: progress with an unknown process. Annual Review of Microbiology 63, 311-334.

Knittel, K., Losekann, T., Boetius, A., Kort, R., Amann, R., 2005. Diversity and distribution of methanotrophic archaea at cold seeps. Applied and Environmental Microbiology 71, 467479.

Kuscu, I., Okamura, M., Matsuoka, H., Gokasan, E., Awata, Y., Tur, H., Simsek, M., Kecer, M., 2005. Seafloor gas seeps and sediment failures triggered by the August 17, 1999 earthquake in the Eastern part of the Gulf of Izmit, Sea of Marmara, NW Turkey. Marine 629 Geology 215, 193-214.

630 Kutterolf, S., Liebetrau, V., Mörz, T., Freundt, A., Hammerich, T., Garbe-Schönberg, D., 631 2008. Lifetime and cyclicity of fluid venting at forearc mound structures determined by 632 tephrostratigraphy and radiometric dating of authigenic carbonates. Geology 36, 707-710.

633 Lachniet, M.S., Bernal, J.P., Asmerom, Y., Polyak, V., 2012. Uranium loss and aragonite634 calcite age discordance in a calcitized aragonite stalagmite. Quaternary Geochronology 14, $635 \quad 26-37$.

636 Lalou, C., Fontugne, M., Lallemand, S.E., Lauriat-Rage, A., 1992. Calyptogena-cemented 637 rocks and concretions from the eastern part of Nankai accretionary prism: Age and 638 geochemistry of uranium. Earth and Planetary Science Letters 109, 419-429.

639 Liebetrau, V., Eisenhauer, A., Linke, P., 2010. Cold seep carbonates and associated cold640 water corals at the Hikurangi Margin, New Zealand: New insights into fluid pathways, growth 641 structures and geochronology. Marine Geology 272, 307-318.

642 Ludwig, K.R., 2009. Isoplot v. 3.71: A geochronological toolkit for Microsoft Excel: 643 Berkeley, California, Berkeley Geochronology Center Special Publication. .

644 Luff, R., Wallmann, K., 2003. Fluid flow, methane fluxes, carbonate precipitation and 645 biogeochemical turnover in gas hydrate-bearing sediments at Hydrate Ridge, Cascadia 646 Margin: numerical modeling and mass balances. Geochimica Et Cosmochimica Acta 647 3403-3421. 
Luff, R., Wallmann, K., Aloisi, G., 2004. Numerical modeling of carbonate crust formation at 649 cold vent sites: significance for fluid and methane budgets and chemosynthetic biological 650 communities. Earth and Planetary Science Letters 221, 337-353.

651 Luth, C., Luth, U., Gebruk, A.V., Thiel, H., 1999. Methane gas Seeps Along the Oxic/Anoxic 652 Gradient in the Black Sea: Manifestations, Biogenic Sediment Compounds and Preliminary 653 Results on Benthic Ecology. Marine Ecology 20, 221-249.

654 Magalhães, V.H., Pinheiro, L.M., Ivanov, M.K., Kozlova, E., Blinova, V., Kolganova, J., 655 Vasconcelos, C., McKenzie, J.A., Bernasconi, S.M., Kopf, A.J., Díaz-del-Río, V., González, 656 F.J., Somoza, L., 2012. Formation processes of methane-derived authigenic carbonates from 657 the Gulf of Cadiz. Sedimentary Geology 243-244, 155-168.

658

659

660

661

662

663

664

665

666

667

668

669

670

671

672

673

674

675

676

677

678

679

680

681

682

683

684

685

686

Mansour, A.S., Sassen, R., 2011. Mineralogical and stable isotopic characterization of authigenic carbonate from a hydrocarbon seep site, Gulf of Mexico slope: Possible relation to crude oil degradation. Marine Geology 281, 59-69.

Mau, S., Rehder, G., Arroyo, I.G., Gossler, J., Suess, E., 2007. Indications of a link between seismotectonics and $\mathrm{CH} 4$ release from seeps off Costa Rica. Geochem. Geophys. Geosyst. 8, Q04003.

McClusky, S., Balassanian, S., Barka, A., Demir, C., Ergintav, S., Georgiev, I., Gurkan, O., Hamburger, M., Hurst, K., Kahle, H., Kastens, K., Kekelidze, G., King, R., Kotzev, V., Lenk, O., Mahmoud, S., Mishin, A., Nadariya, M., Ouzounis, A., Paradissis, D., Peter, Y., Prilepin, M., Reilinger, R., Sanli, I., Seeger, H., Tealeb, A., Toksoz, M.N., Veis, G., 2000. Global Positioning System constraints on plate kinematics and dynamics in the eastern Mediterranean and Caucasus. J. Geophys. Res.-Solid Earth 105, 5695-5719.

McHugh, C.M.G., Gurung, D., Giosan, L., Ryan, W.B.F., Mart, Y., Sancar, U., Burckle, L., Çagatay, M.N., 2008. The last reconnection of the Marmara Sea (Turkey) to the World Ocean: A paleoceanographic and paleoclimatic perspective. Marine Geology 255, 64-82.

Menot, G., Bard, E., 2010. Geochemical evidence for a large methane release during the last deglaciation from Marmara Sea sediments. Geochimica Et Cosmochimica Acta 74, 15371550 .

Millo, C., Sarnthein, M., Erlenkeuser, H., Frederichs, T., 2005. Methane-driven late Pleistocene $\delta 13 \mathrm{C}$ minima and overflow reversals in the southwestern Greenland Sea. Geology 33, 873-876.

Morse, J.W., Wang, Q., Tsio, M.Y., 1997. Influences of temperature and Mg:Ca ratio on $\mathrm{CaCO} 3$ precipitates from seawater. Geology 25, 85-87.

Nöthen, K., Kasten, S., 2011. Reconstructing changes in seep activity by means of pore water and solid phase $\mathrm{Sr} / \mathrm{Ca}$ and $\mathrm{Mg} / \mathrm{Ca}$ ratios in pockmark sediments of the Northern Congo Fan. Marine Geology 287, 1-13.

Obzhirov, A., Shakirov, R., Salyuk, A., Suess, E., Biebow, N., Salomatin, A., 2004. Relations between methane venting, geological structure and seismo-tectonics in the Okhotsk Sea. GeoMarine Letters 24, 135-139. 
688 Consuming Archaea Revealed by Directly Coupled Isotopic and Phylogenetic Analysis.

689 Science 293, 484-487.

690 Pallasser, R.J., 2000. Recognising biodegradation in gas/oil accumulations through the

691 [delta]13C compositions of gas components. Organic Geochemistry 31, 1363-1373.

692 Paull, C.K., Hecker, B., Commeau, R., Freemanlynde, R.P., Neumann, C., Corso, W.P.,

693 Golubic, S., Hook, J.E., Sikes, E., Curray, J., 1984. Biological Communities at the Florida

694 Escarpment Resemble Hydrothermal Vent Taxa. Science 226, 965-967.

695 Peckmann, J., Reimer, A., Luth, U., Luth, C., Hansen, B.T., Heinicke, C., Hoefs, J., Reitner,

696 J., 2001. Methane-derived carbonates and authigenic pyrite from the northwestern Black Sea.

697 Marine Geology 177, 129-150.

698 Peckmann, J., Thiel, V., 2004. Carbon cycling at ancient methane-seeps. Chemical Geology $699205,443-467$.

700 Reeburgh, W.S., 1976. Methane consumption in Cariaco Trench waters and sediments. Earth 701 and Planetary Science Letters 28, 337-344.

702 Reichel, T., Halbach, P., 2007. An authigenic calcite layer in the sediments of the Sea of

703 Marmara--A geochemical marker horizon with paleoceanographic significance. Deep Sea

704 Research Part II: Topical Studies in Oceanography 54, 1201-1215.

705 Reilinger, R.E., McClusky, S.C., Oral, M.B., King, R.W., Toksoz, M.N., Barka, A.A., Kinik, 706 I., Lenk, O., Sanli, I., 1997. Global Positioning System measurements of present-day crustal 707 movements in the Arabia-Africa-Eurasia plate collision zone. J. Geophys. Res.-Solid Earth 708 102, 9983-9999.

709 Ritger, S., Carson, B., Suess, E., 1987. Methane-Derived Authigenic Carbonates Formed by 710 Subduction Induced Pore-Water Expulsion Along the Oregon Washington Margin.

711 Geological Society of America Bulletin 98, 147-156.

712 Robinson, L.F., Belshaw, N.S., Henderson, G.M., 2004. U and Th concentrations and isotope 713 ratios in modern carbonates and waters from the Bahamas. Geochimica Et Cosmochimica 714 Acta 68, 1777-1789.

715 Ruffine, L., Fandino, T.O., Etoubleau, J., Cheron, S., Donval, J.-P., Germain, Y., Ponzevera, 716 E., Guyader, V., Dennielou, B., Etiope, G., Gasperini, L., Bortoluzzi, G., Henry, P., Grall, C., 717 Cagatay, M.N., Charlou, J.-L., Géli, L., 2012. Geochemical Dynamics of the Natural-Gas 718 Hydrate System in the Sea of Marmara, Offshore Turkey. Advances in Natural Gas 719 Technology.

720 Sassen, R., Roberts, H.H., Carney, R., Milkov, A.V., DeFreitas, D.A., Lanoil, B., Zhang, C.,

721 2004. Free hydrocarbon gas, gas hydrate, and authigenic minerals in chemosynthetic communities of the northern Gulf of Mexico continental slope: relation to microbial processes. Chemical Geology 205, 195-217. 
Schrag, D.P., Higgins, J.A., Macdonald, F.A., Johnston, D.T., 2013. Authigenic Carbonate and the History of the Global Carbon Cycle. Science 339, 540-543.

Sheppard, S.M.F., Gilg, H.A., 1996. Stable isotope geochemistry of clay minerals. Clay Min. $31,1-24$.

730 Sibuet, M., Olu, K., 1998. Biogeography, biodiversity and fluid dependence of deep-sea coldseep communities at active and passive margins. Deep-Sea Res. Part II-Top. Stud. Oceanogr. 45, 517-+.

Sperling, M., Schmiedl, G., Hemleben, C., Emeis, K.C., Erlenkeuser, H., Grootes, P.M., 2003. Black Sea impact on the formation of eastern Mediterranean sapropel S1? Evidence from the Marmara Sea. Palaeogeography Palaeoclimatology Palaeoecology 190, 9-21.

Stadnitskaia, A., Nadezhkin, D., Abbas, B., Blinova, V., Ivanov, M.K., Damste, J.S.S., 2008. Carbonate formation by anaerobic oxidation of methane: Evidence from lipid biomarker and fossil 16S rDNA. Geochimica Et Cosmochimica Acta 72, 1824-1836.

Stakes, D.S., Orange, D., Paduan, J.B., Salamy, K.A., Maher, N., 1999. Cold-seeps and authigenic carbonate formation in Monterey Bay, California. Marine Geology 159, 93-109.

Stanley, D.J., Blanpied, C., 1980. Late Quaternary water exchange between the eastern Mediterranean and the Black Sea. Nature 285, 537-541.

Teichert, B.M.A., Eisenhauer, A., Bohrmann, G., Haase-Schramm, A., Bock, B., Linke, P., 2003. U/Th systematics and ages of authigenic carbonates from Hydrate Ridge, Cascadia

Margin: recorders of fluid flow variations. Geochimica Et Cosmochimica Acta 67, 3845-3857.

746

747
Tolun, L., Çagatay, M.N., Carrigan, W.J., 2002. Organic geochemistry and origin of Late Glacial-Holocene sapropelic layers and associated sediments in Marmara Sea. Marine Geology 190, 47-60.

Tryon, M.D., Brown, K.M., Torres, M.E., 2002. Fluid and chemical flux in and out of sediments hosting methane hydrate deposits on Hydrate Ridge, OR, II: Hydrological processes. Earth and Planetary Science Letters 201, 541-557.

Tryon, M.D., Henry, P., Çağatay, M.N., Zitter, T.A.C., Géli, L., Gasperini, L., Burnard, P., Bourlange, S., Grall, C., 2010. Pore fluid chemistry of the North Anatolian Fault Zone in the Sea of Marmara: A diversity of sources and processes. Geochem. Geophys. Geosyst. 11, Q0AD03.

Valentine, D.L., 2002. Biogeochemistry and microbial ecology of methane oxidation in anoxic environments: a review. Antonie Van Leeuwenhoek 81, 271-282.

Valentine, D.L., Reeburgh, W.S., 2000. New perspectives on anaerobic methane oxidation. Environmental Microbiology 2, 477-484.

Vanneste, H., Kastner, M., James, R.H., Connelly, D.P., Fisher, R.E., Kelly-Gerreyn, B.A., Heeschen, K., Haeckel, M., Mills, R.A., 2012. Authigenic carbonates from the Darwin Mud Volcano, Gulf of Cadiz: A record of palaeo-seepage of hydrocarbon bearing fluids. Chemical Geology 300-301, 24-39. 
764 Vidal, L., Menot, G., Joly, C., Bruneton, H., Rostek, F., Çağatay, M.N., Major, C., Bard, E., 765 2010. Hydrology in the Sea of Marmara during the last $23 \mathrm{ka}$ : Implications for timing of

766 Black Sea connections and sapropel deposition. Paleoceanography 25.

767 Watanabe, Y., Nakai, S.i., Hiruta, A., Matsumoto, R., Yoshida, K., 2008. U-Th dating of 768 carbonate nodules from methane seeps off Joetsu, Eastern Margin of Japan Sea. Earth and 769 Planetary Science Letters 272, 89-96.

770 Wood, W.T., Gettrust, J.F., Chapman, N.R., Spence, G.D., Hyndman, R.D., 2002. Decreased 771 stability of methane hydrates in marine sediments owing to phase-boundary roughness.

772 Nature 420, 656-660.

773 Yokoyama, Y., Lambeck, K., De Deckker, P., Johnston, P., Fifield, L.K., 2000. Timing of the 774 Last Glacial Maximum from observed sea-level minima. Nature 406, 713-716.

775 Zitter, T.A.C., Henry, P., Aloisi, G., Delaygue, G., Çağatay, M.N., de Lepinay, B.M., Al776 Samir, M., Fornacciari, F., Tesmer, M., Pekdeger, A., Wallmann, K., Lericolais, G., 2008. 777 Cold seeps along the main Marmara Fault in the Sea of Marmara (Turkey). Deep-Sea

778 Research Part I-Oceanographic Research Papers 55, 552-570. 
3 Figure 1: (A) Bathymetry of the Sea of Marmara with sampling locations (white hexagons:

4 seafloor carbonate crusts, green hexagons: carbonate chimneys expelling glacial brackish

5 water, red star: coring site). (B) Tectonic setting of the eastern Mediterranean region. Arrows indicate relative plate motion and red box shows study area of the Sea of Marmara.

Figure 2: Seafloor images of seep carbonates constructions acquired during the Nautile dives and cross-sections of authigenic carbonates. Yellow stars represent micro-drill sampling for U-Th and stable isotopes analysis whereas black arrows indicate surface coating ferromanganeous oxy-hydroxide. (A) Mud-breccia, sample 1647-R1; Tekirdağ Basin (B) Carbonate covered by a black layer of oxy-hydroxides, sample 1653-R3; Çinarcik Basin (C) Carbonate crust, sample 1667-R1; Tekirdağ Basin (D) Carbonate concretions, sample MNTKS14, 1.08 mbsf; Western-High (E) sample MNT-KS14, 1.63 mbsf; Western-High.

Figure 3: SEM photomicrographs of authigenic carbonates. (A) Radial-fibrous authigenic aragonite needles, sample 1653-R5; Çinarcik Basin (B) Single crystals of radial-fibrous aragonite, sample 1653-R3; Çinarcik Basin (C) Epitaxial radial-fibrous aragonite with different crystals size between the inner and outer part, sample MNT-KS14, 1.67 mbsf;

20 Western-High.

Figure 4: Isochron diagram of sediments end-members used for U-Th carbonate ages calculations. The dashed line represents the equiline (slope $=1$ ) indicating minerals that reach

24 the secular equilibrium of the ${ }^{230} \mathrm{Th}-{ }^{238} \mathrm{U}$ system (age $>350 \mathrm{kyr}$ ). Difference between the 
theoretical and the experimental end-members can be explained by the presence of small sized biogenic carbonates unobserved under binocular inspection (e.g. coccoliths).

Figure 5: Stable carbon and oxygen isotopic compositions of micro-drill authigenic

carbonates, dashed line represents the theoretical $\delta^{18} \mathrm{O}$ values for aragonite that precipitated in equilibrium with modern bottom waters conditions $\left(\mathrm{T}=14.5^{\circ} \mathrm{C}\right.$ and $\delta^{18} \mathrm{O}_{\text {water }}=+1.4 \%$ o VSMOW).

Figure 6: Rosholt isochron and age frequencies of micro-drilled carbonates. Dashed lines represent examples of age from some samples. Note that ages which are not well constrain presents low $\left({ }^{238} \mathrm{U} /{ }^{232} \mathrm{Th}\right)$ and $\left({ }^{230} \mathrm{Th} /{ }^{232} \mathrm{Th}\right)$ ratios. (A) Isochron diagram of seafloor authigenic carbonates crusts and histogram of absolute U-Th crusts ages (round up unity) against age frequency. (B) Isochron diagram of buried carbonate concretions and histogram of absolute U-Th concretions ages (round up unity) against age frequency.

Figure 7: Absolute high Mg-calcite content (wt \%) versus bulk carbon isotopic composition of concretions from Western-High cores (data from Crémière et al., 2012). Carbonate concretions from core MNT-KS14 are mainly composed of aragonite whereas concretions from core MNT-KS27 are mainly composed of high Mg-calcite.

Figure 8: Cores description, total carbonate content of bulk sediments, stable carbon and oxygen isotopic compositions of bulk sediments and cemented authigenic carbonates (data in supplementary materials and from Crémière et al., (2012)). The sulfate-methane transition zone (SMTZ) is deduced from pore water geochemistry (Tryon et al., 2010). 
50 Figure 9: Timeline of paleo-environemental events and U-Th ages of carbonates with error

51 bars $\left({ }^{1}\right.$ Vidal et al., 2010, ${ }^{2}$ Çağatay et al., 2000, ${ }^{3}$ Menot et al., 2011, ${ }^{4}$ Reichel et al., 2007).

53 Figure 10: (A) Relative timing of authigenic carbonate precipitation versus the global sea

54 level curve (modified from Lambeck et al., 2002). The depth of the Dardanelles sill (in grey)

55 represents the Mediterranean sulfate-rich waters inflow in the brackish Marmara Lake. (B)

56 Sedimentary total organic carbon in sediments revealing the sapropel event in grey (modified

57 from Vidal et al. 2010) at Western-High ridge compared to carbonates dating from core

58 MNT-KS14. (A) The inflow of Mediterranean seawater over the Dardanelles sill

59 (approximately $80 \mathrm{~m}$ water depth) delivers sulfate for AOM and the precipitation of authigenic

60 carbonates. (B) Carbonate precipitation occurred at high TOC contents within a sapropelic

61 deposition. 


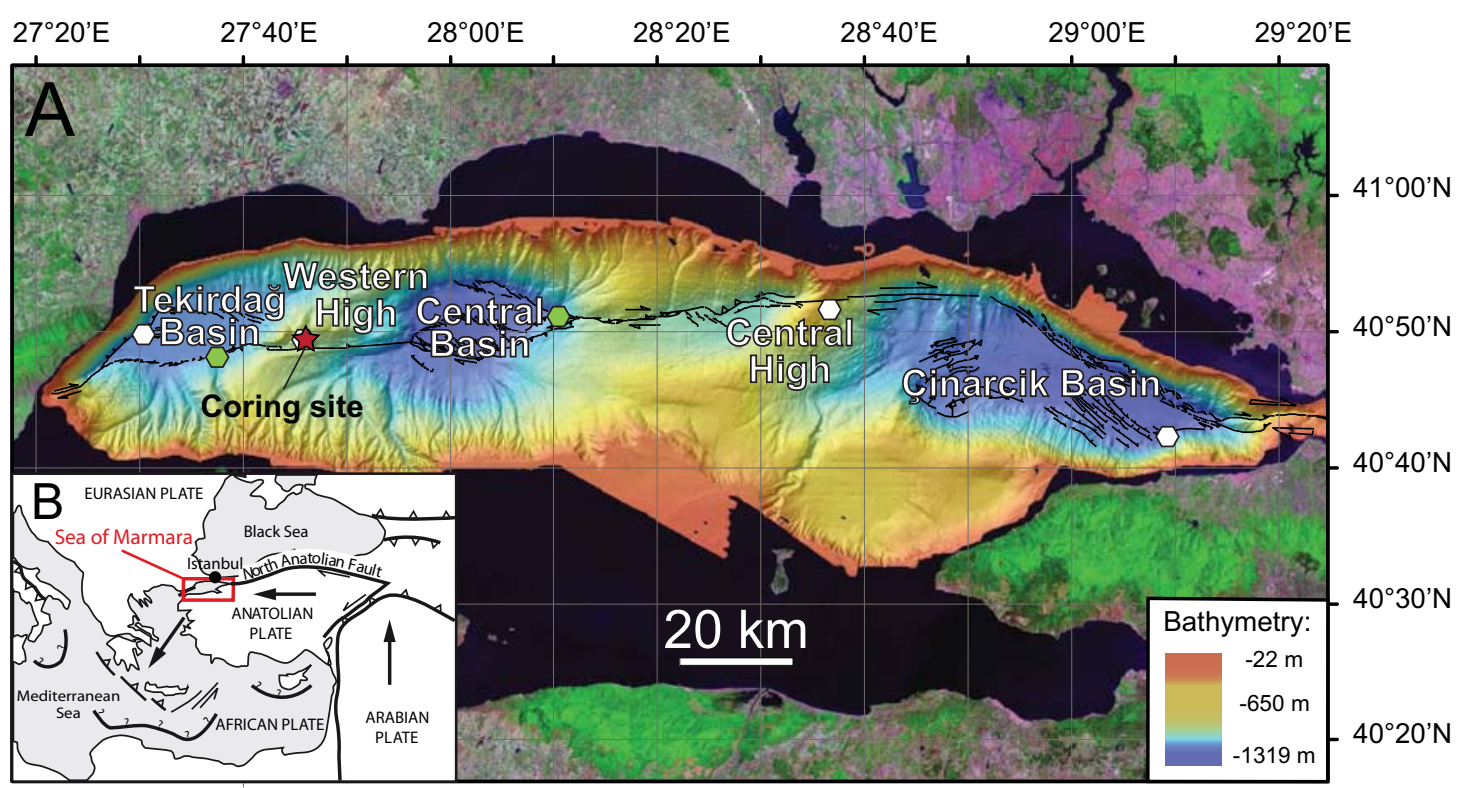


Seafloor exploration

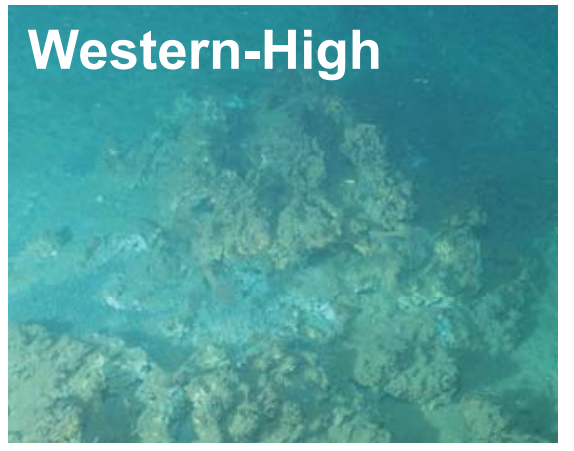

Carbonate crusts

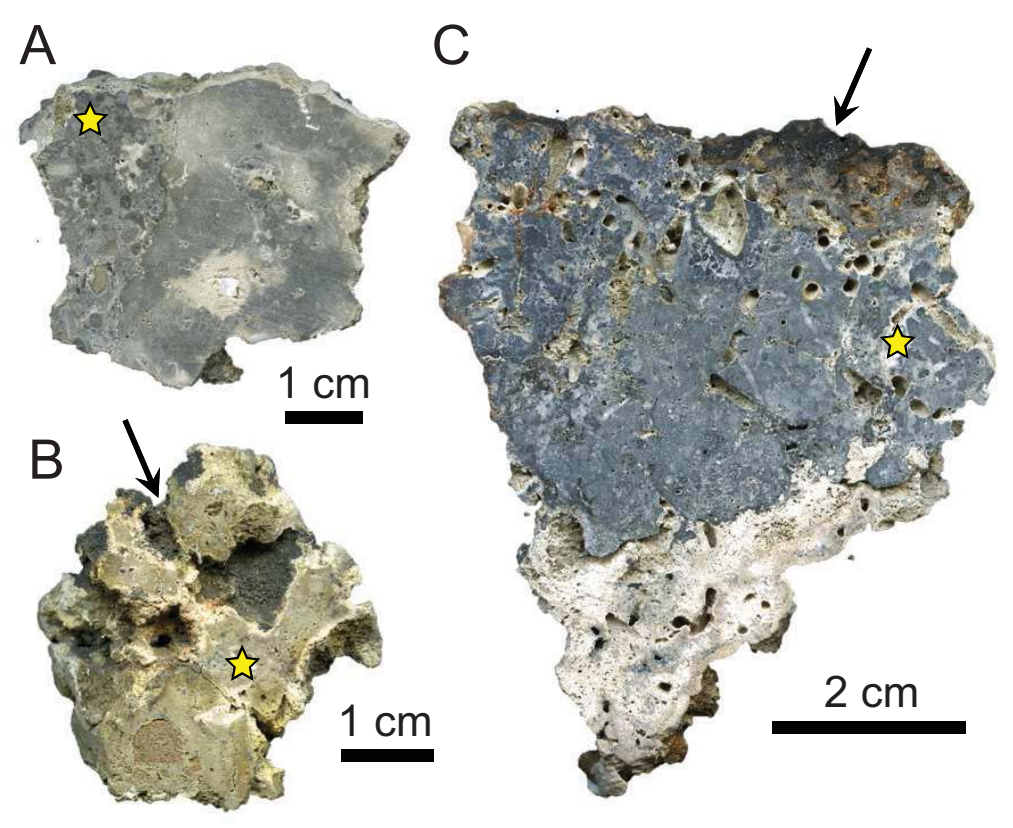

Carbonate concretions

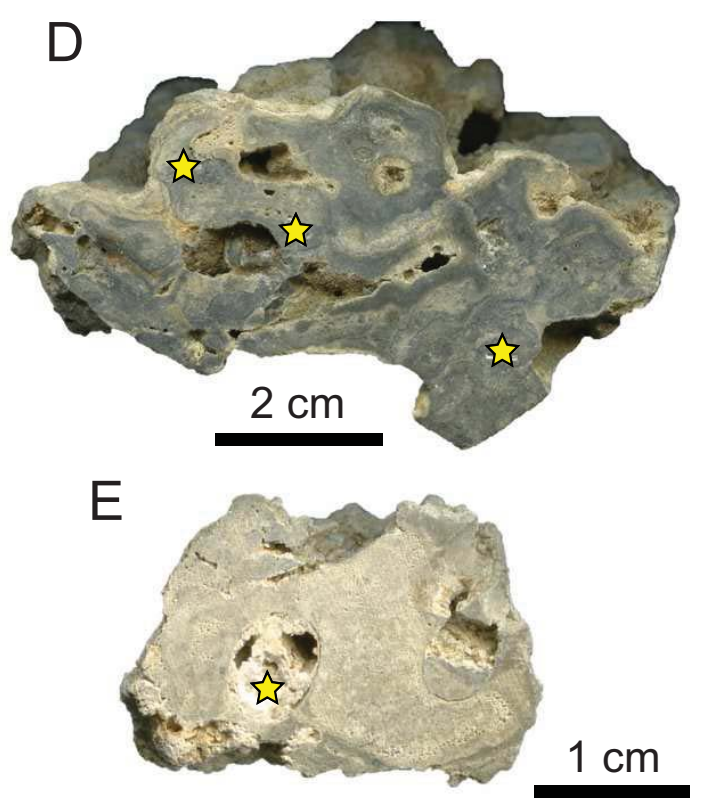




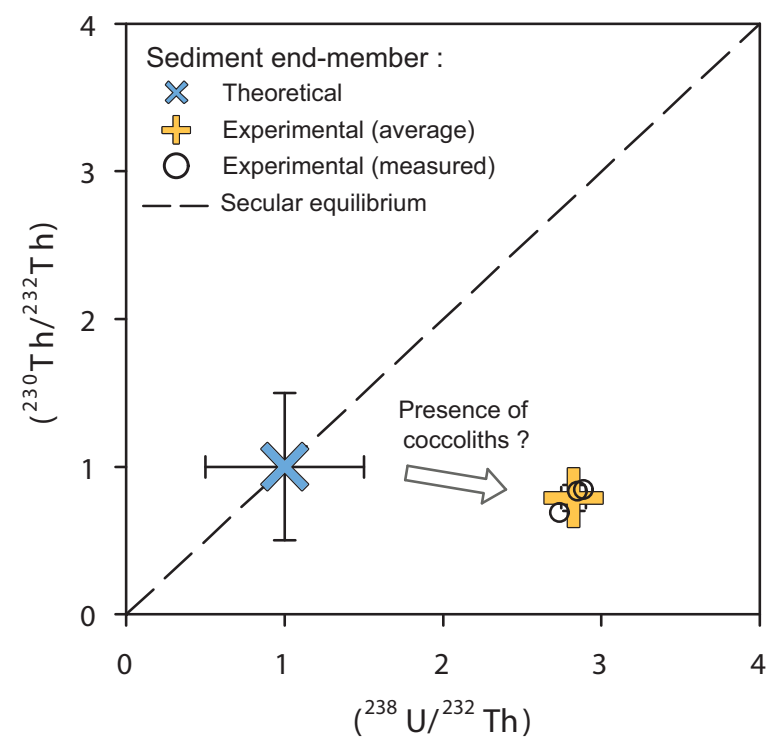




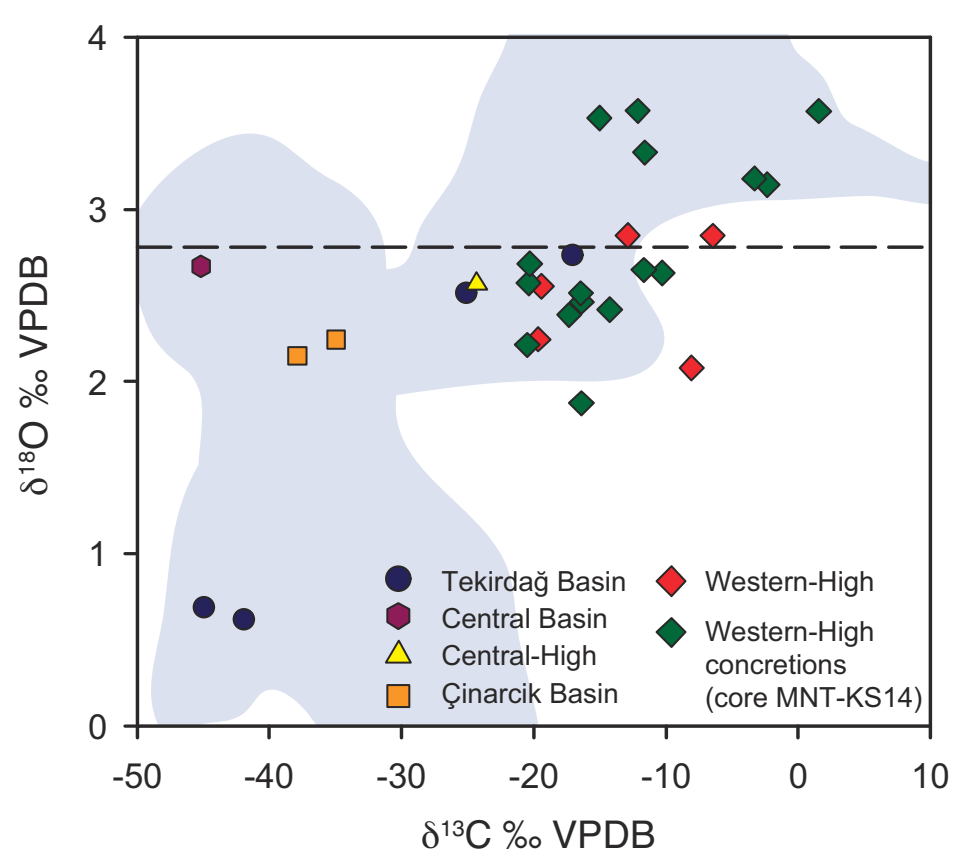


A) Seafloor authigenic carbonates
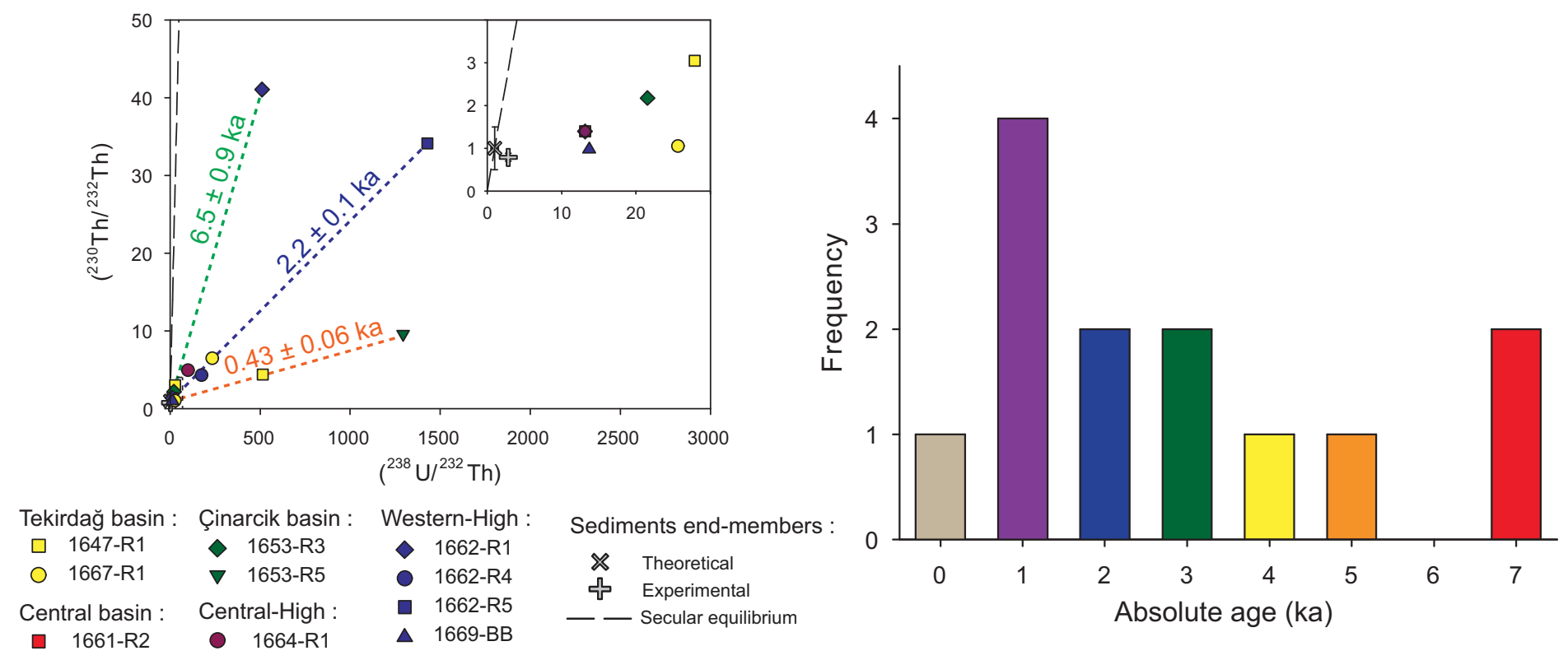

B) Buried carbonate concretions (Core MNT-KS14, Western-High ridge)

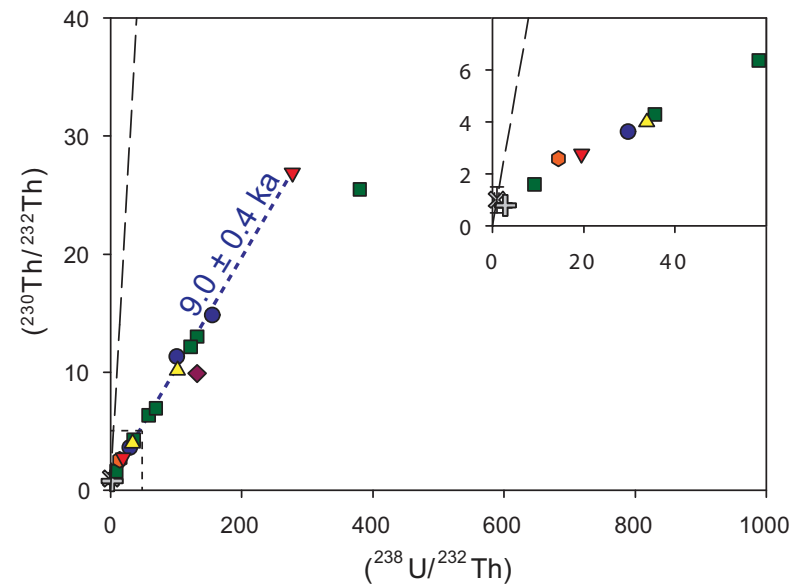

Carbonate concretions :

- MNT-KS14, 0.98 mbsf

MNT-KS14, $1.03 \mathrm{mbsf}$

$\triangle$ MNT-KS14, $1.23 \mathrm{mbsf}$

Sediments end-members :

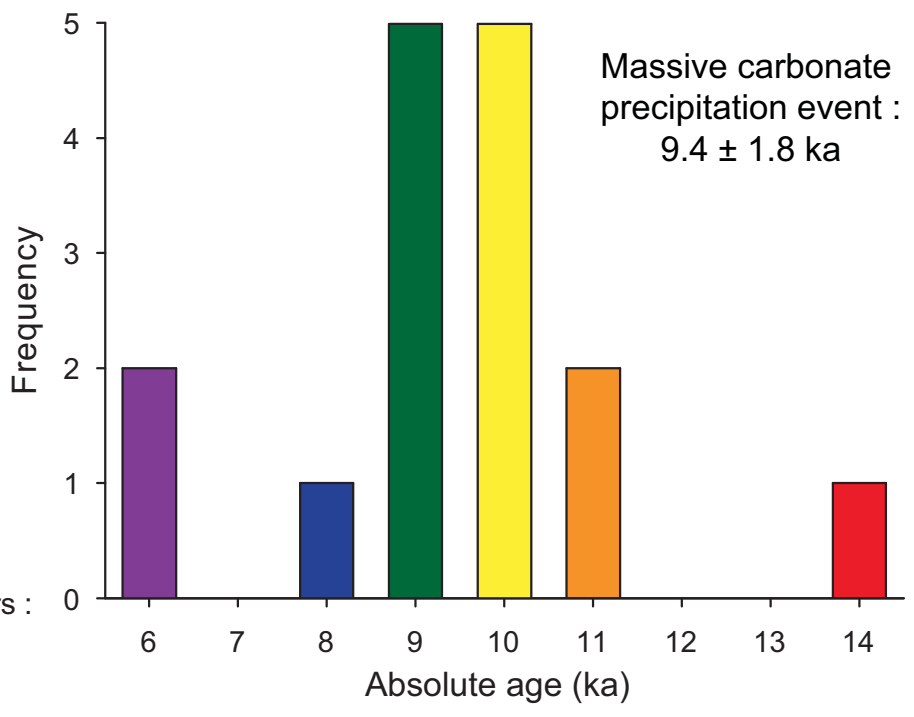

MNT-KS14, $1.08 \mathrm{mbsf}$

O MNT-KS14, $1.48 \mathrm{mbsf}$

$\bowtie$ Theoretical

§ Experimental

Absolute age (ka)

Massive carbonate

$9.4 \pm 1.8 \mathrm{ka}$

- Secular equilibrium 


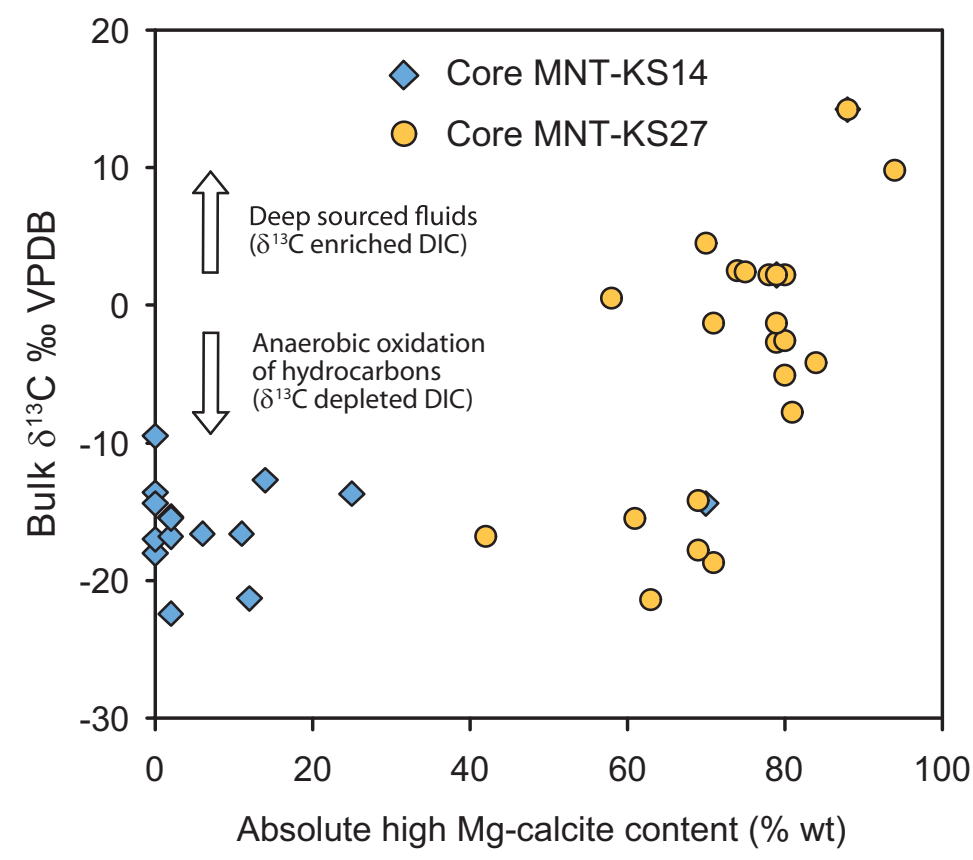




\section{A) MNT-KS14}

$655 \mathrm{~m}$ water depth

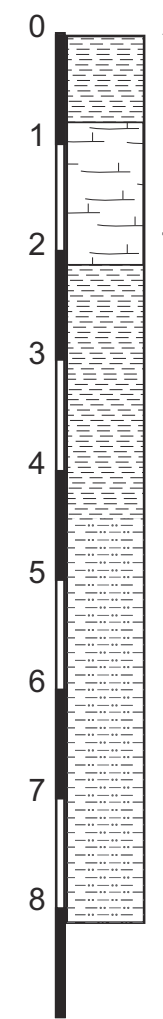

Total carbonate content (wt\%)

$\delta^{13} \mathrm{C} \%$ \% VPDB

$\delta^{18} \mathrm{O} \%$ o VPDB

$\begin{array}{llllllllllllllll}0 & 5 & 10 & 15 & 20 & 25 & 30 & -20 & -10 & 0 & 10 & -6 & -4 & -2 & 0 & 2\end{array}$

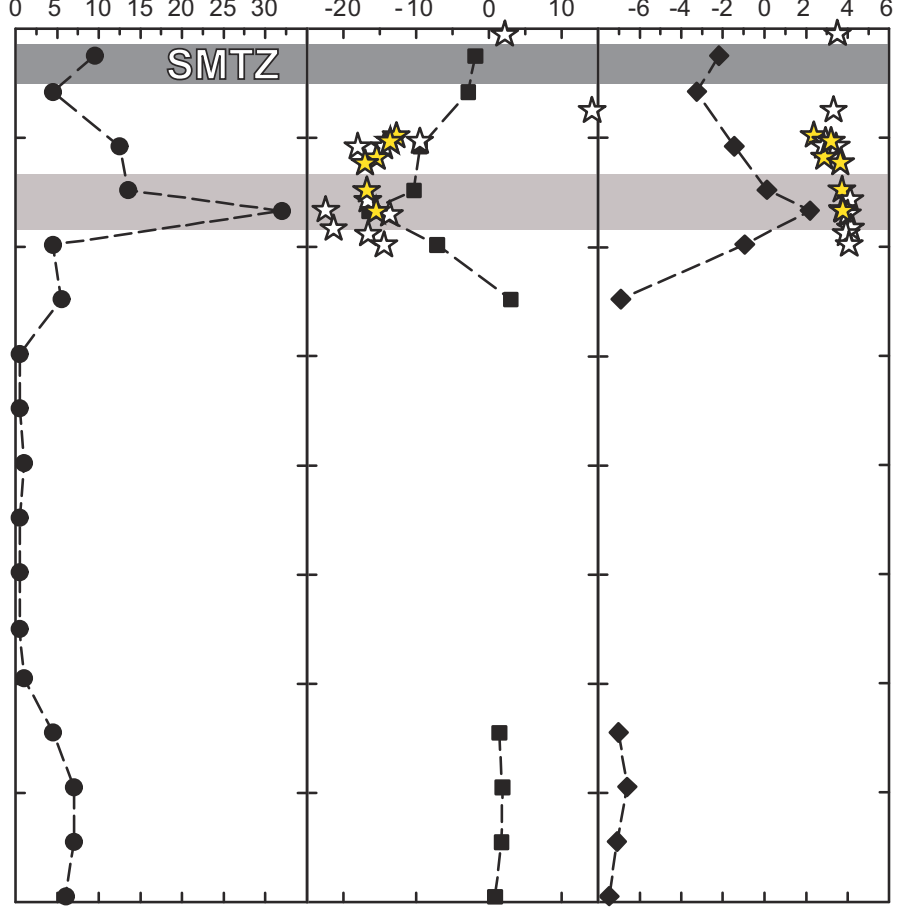

Authigenic carbonates mineralogy

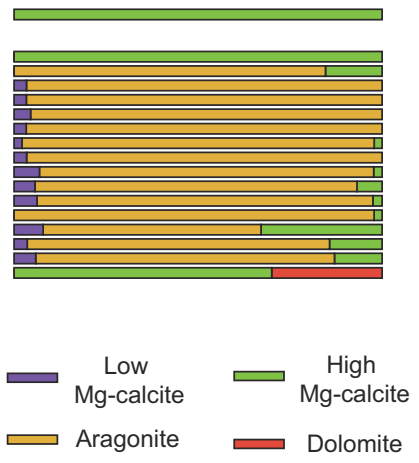

Legend:

is Carbonate concretions

tr U-Th dating : $9.4 \pm 1.8 \mathrm{ka}$

Bulk sediment

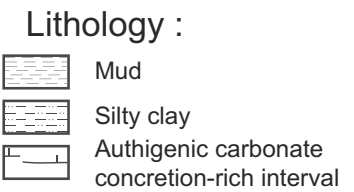

\section{B) MNT-KS27}

$669 \mathrm{~m}$ water depth

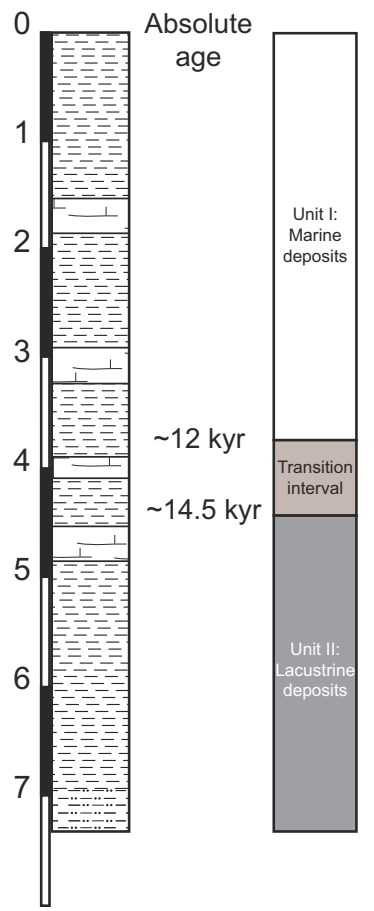

Total carbonate content (wt\%)

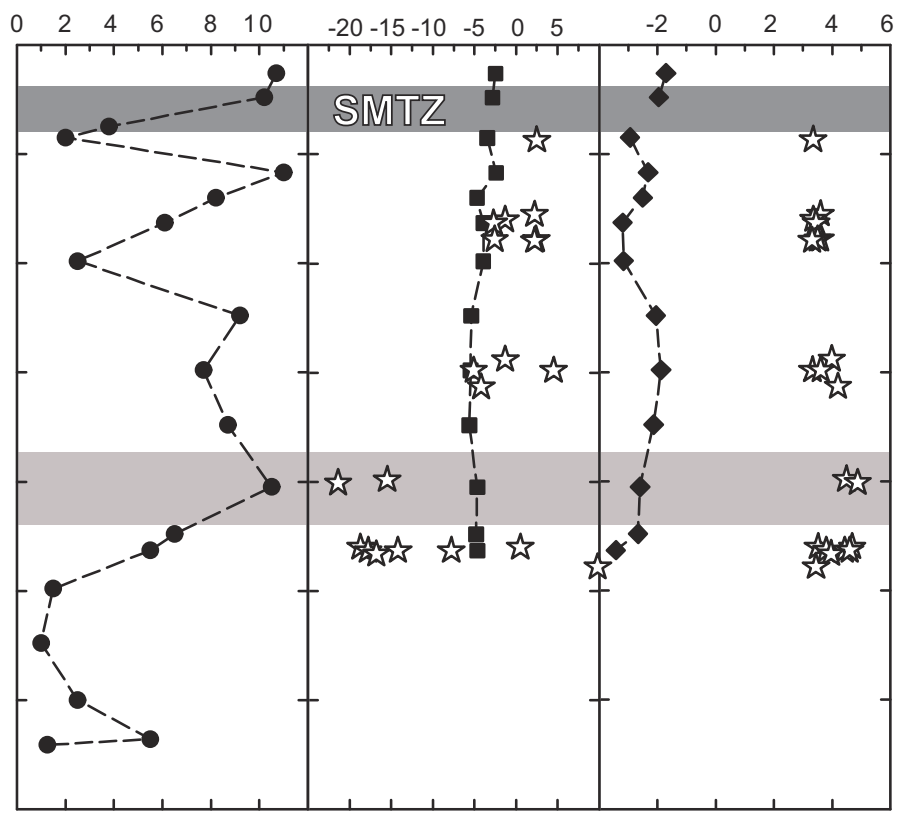

Authigenic carbonates mineralogy

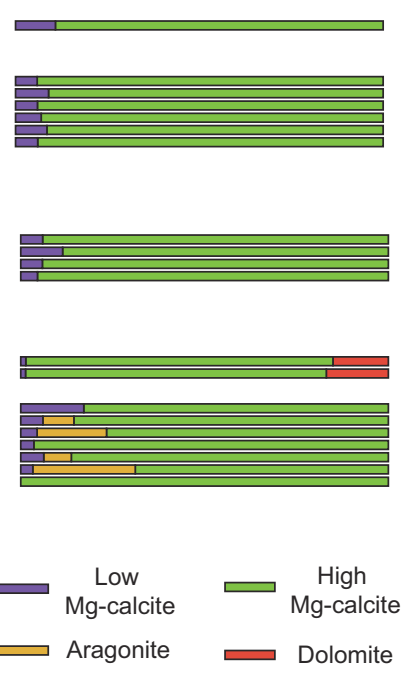




\section{Paleo-event :}

Seafloor authigenic carbonates

Buried concretions from Western-High ridge

Sapropelic deposits ${ }^{(1,2)}$

Methane escape in the water column ${ }^{(3)}$

Authigenic calcite precipitation ${ }^{(4)}$

Marine transgression ${ }^{(1)}$

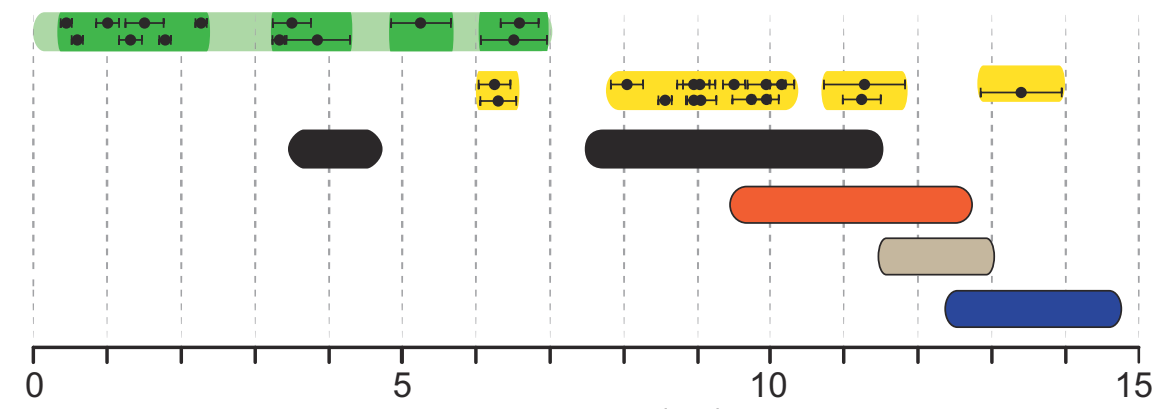

Absolute age (kyr) 

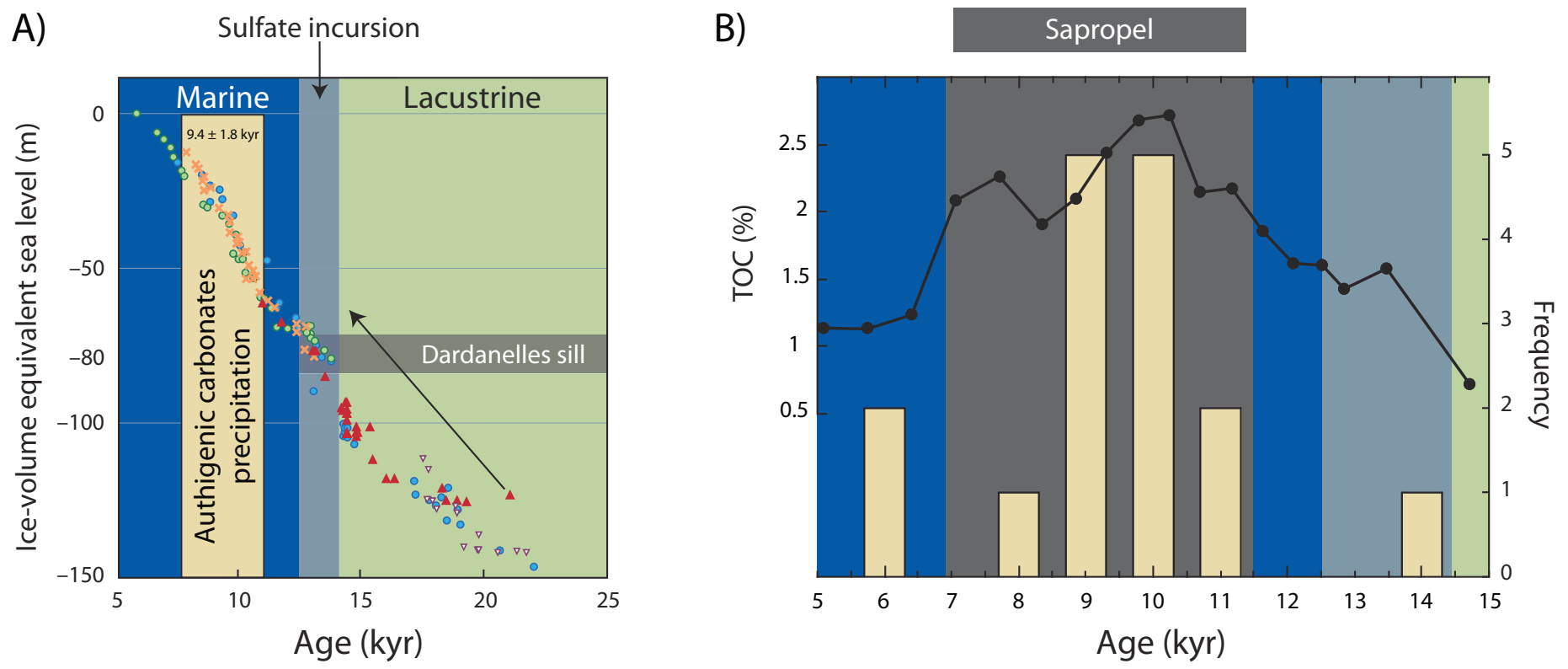